Historic, Archive Document

Do not assume content reflects current scientific knowledge, policies, or practices. 



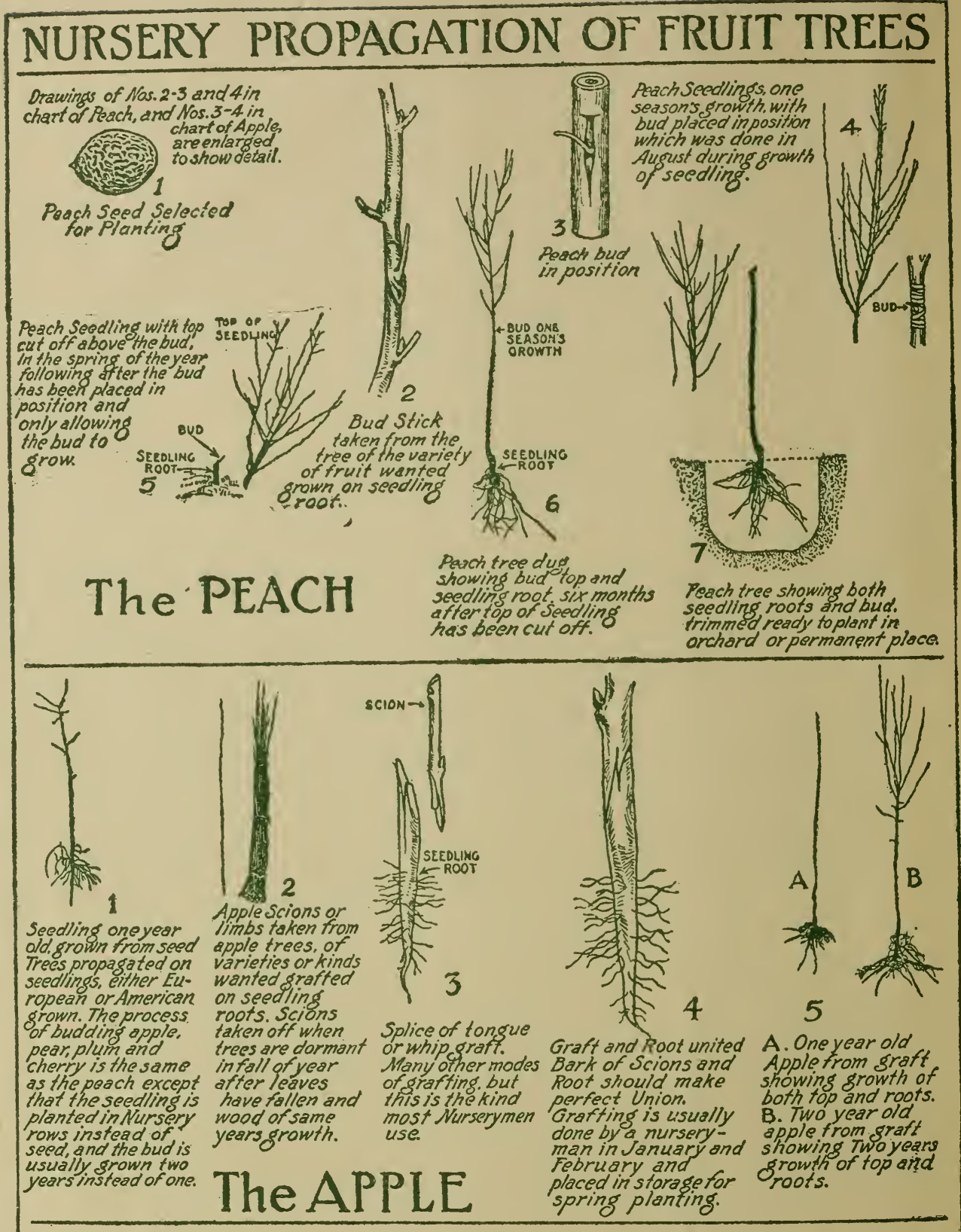

Apple trees can be propagated either on apple seedlings, haws or thorn. Plum trees can be budded on almost any kind of wild plum stock or peach seedlings. Myrobolan Plum stock is usually used by Nurserymen.

Cherry, budded on almost any wild cherry stock, but Myhaleb or Mazzard cherry stock is usually used by Nurserymen.

Pear is budded on French pear seedlings, Kieffer and Japan pear seedlings, but French pear seedlings is preferred by nurserymen.

Dwarf Pear are propagated on Quince roots.

Dwarf Apple are propagated on Doucin and Paradise stock grown from cuttings. All fruits can be grafted, but seldom any of them are grafted for nursery growing except apple. 


\title{
WHAT, WHERE, WHEN
}

A N D

\author{
How to Plant
}

\section{Fruit and Ornamental Trees}

Berry Plants, Roses, Shrubs, Evergreens, Vines and

\author{
Perennials
}

FACTS ON FOUR QUESTIONS THAT

EVERYONE WANTS TO KNOW

FIRST EDITION COPYRIGHT 1913

REVISED SECOND EDITION COPYRIGHT 1914.

By E. E. BOHLENDER. Tippecanoe City, (Miami Co.) Ohio

\section{ENDORSED BY}

Mr. Frank Miller, State Superintendent of Schools, Columbus, O.

Mr. Peter Bissett, Plant Introducers in charge of foreign plant distribution, Washington, D. C.

Mr. Lester S. Ivins, Supervisor of Agriculture, Lebanon, O.

State Experimental Stations.

Superintendents and Principals of Schools.

Landscape Gardeners.

Nurserymen, Seedmen, Florists and many others. 

careful selection of the location, whether the product is for home or commercial purpose. Consider well the slope of the land, the kind of soil, the drainage and the varieties that are best adapted to that special locality. The safest way to select the varieties you wish to plant is to study those that are doing well and are most profitable, in the immediate vicinity of the proposed orchard.

TRUE ECONOMY It will always be found to be true economy to buy the very best trees, plants, etc., as to quality, that can be had. They need not be the largest stock, but stock that is guaranteed to be first class as to quality and free from disease and injurious insects.

A first-class fruit tree is one that is healthy, well grown, well dug and free from disease and injurious insects. Other things being equal, it is best to select a tree one or two years old. Older trees may be successfully planted, but the younger ones are more satisfactory, are handled more easily, suffer less in transplanting and are more profitable in the long run.

For a town lot dwarf fruits are frequently desirable. They require less space than the standard varieties. If necessary they may be trained on the side of a building or the fence.

Early ordering is to the advantage of the buyer because he can get the varieties ordered.

When sending in an order, always state mode of shipment.

If stock, when packed for shipment does not exceed 100 pounds in weight, it is better to ship by express, so that the stock need not be out of the ground long. However, if the packing has been well done they may be shipped by freight with safety.

THE TIME TO PLANT depends upon the latitude, but in most states the late fall or early spring, before the foliage appears, is preferable.

\section{PREPARING THE LAND}

It is important when preparing the land, selected as the orchard site, to till deeply and thoroughly. It is also advantageous, when possible, to prepare the soil late in the preceding autumn.

\section{DIGGING THE HOLE}

area is plowed. Should there be a hard pan, or hard stratum of earth or rock underlying the surface soil, it is best to break it up with a subsoil plow, or if possible by dynamiting. The holes should be large enough to accomodate all the roots when properly spread out and allow some extra space for their growth. The tree when planted should be a little deeper in the soil than it was in the nursery row. This can be told by the color of the bark.
It is rarely advisable to merely dig holes in the sod to plant the trees; much better results' will be obtained if the whole
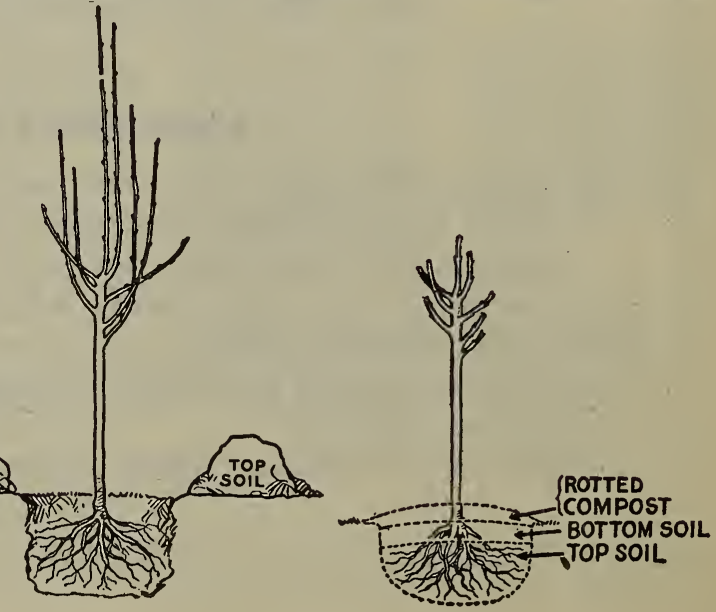


\section{PRUNING WHEN PLANTED $\begin{aligned} & \text { Much } \\ & \text { wi } 11\end{aligned}$}

depend on the proper treatment of trees at the time of planting. During the digging and the handling of the tree some of the roots are sure to be bruised or broken. These must all be trimmed with a sharp knife with a slant on the under side. It may also be well to trim out some of the crowding roots.

The top should also be pruned. (That is, trimmed with sharp knife.) There are some principles which can be explained, but this is something that can only be explained by experience. A tree can be trained or molded to a wonderful extent, and he who prunes intelligently will surely get good results.

Decide when the trees are planted the height at which the top or head is to start. Think first, of the best possible shape and size. For most practical purposes and for most trees, a low and open head is desirable; low, because it can be worked over better, and open so the light and air

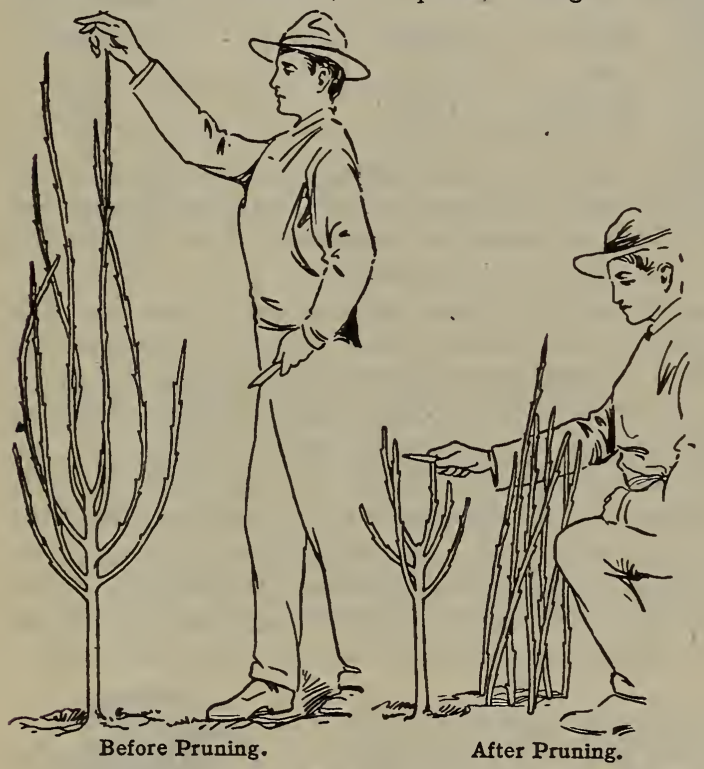

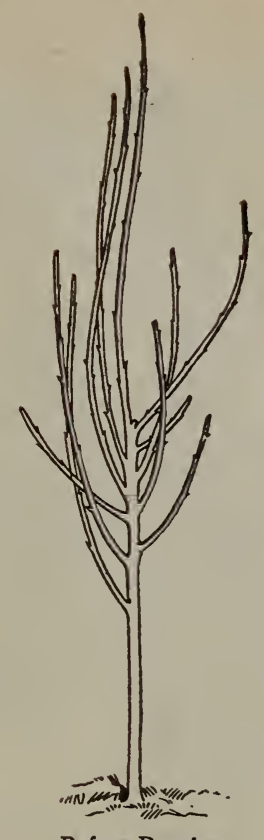

Before Pruning.

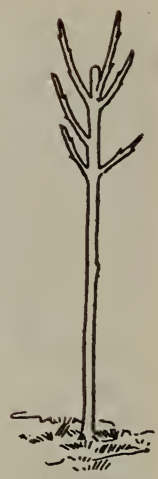

After Pruning.

can reach all the leaves and fruits. A limb never gets any higher from the ground than it is when it starts. Some trees, such as the "Peach" trees, have to be cut back to a mere switch. With "Apple" and "Quince" trees, old enough to be branched, select the limbs wanted for the framework of the head, and nip these back to buds, growing in the direction the branches are to continue. Always remember never to allow two cut limbs to grow opposite each other as this will form a fork so the tree will be likely to split when heavily loaded with fruit or when in the path of a windstorm.

PLANT IMMEDIATELY them, (unless they are frozen in which case allow them to thaw out slowly in a cool cellar), shake out the packing material, dip the roots in a thin mud, and either "heel them in" or plant at once. To "heel them in" have a trench dug deep enough to receive the roots of the trees and cover with earth, shaking well around the roots so no air remains around them to dry them out. This is done just to keep the trees in good condition until a suitable time to set them out.

They are dipped in mud so as to moisten every part-the mud clings to the roots better than just water. This serves the same purpose for trees as putting flowers in water does for them. Never allow the trees to remain at the express office or

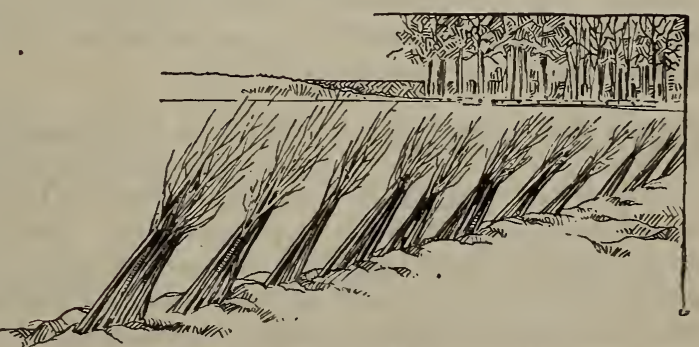

Showing Method of Heeling-in Trees. thin mud, and either "heel them in" or plant at 

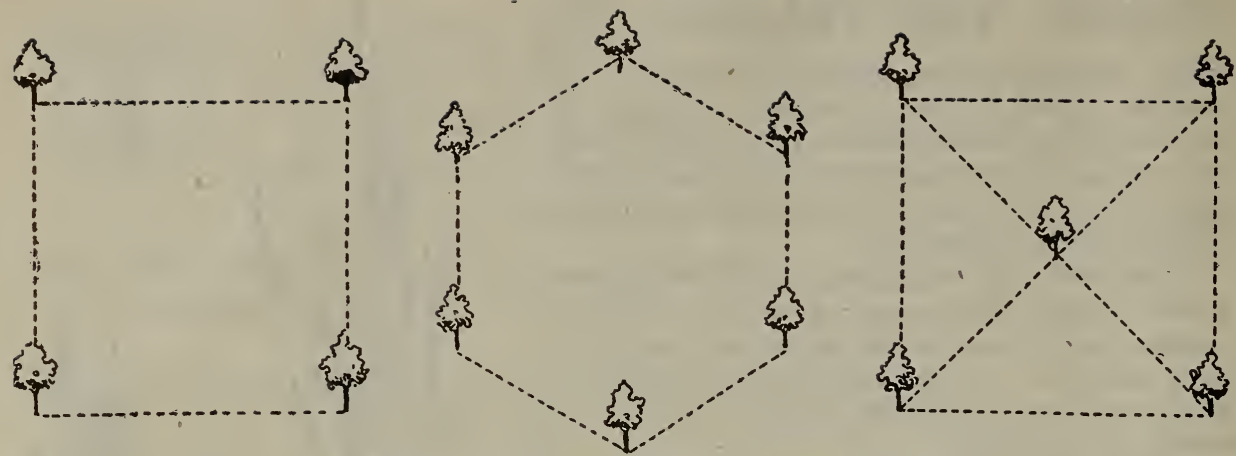

Plans for Planting Orchard to Good Advantage.

\begin{tabular}{|c|c|c|c|c|}
\hline \multirow[b]{2}{*}{ SYSTEM } & \multicolumn{2}{|c|}{ Distance Apart } & \multicolumn{2}{|c|}{ No. of Trees per Acre } \\
\hline & Permanent & Fillers & Permanent & $\begin{array}{l}\text { Permanent } \\
\text { and Fillers }\end{array}$ \\
\hline $\begin{array}{l}\text { Heaxgonal. . } \\
\text { Square..... } \\
\text { Quincunx.. }\end{array}$ & $\begin{array}{l}30 \mathrm{ft} . \\
30 \mathrm{ft} . \\
30(21.2)\end{array}$ & $\begin{array}{l}15 \mathrm{ft} . \\
15 \mathrm{ft} . \\
15 \mathrm{ft} .\end{array}$ & $\begin{array}{l}55 \\
48 \\
97\end{array}$ & $\begin{array}{l}226 \\
194 \\
194\end{array}$ \\
\hline
\end{tabular}

APPLE

Apple trees should be planted from thirty to forty feet apart, since they feed over a large area if they have the opportunity. Plenty of room is also needed for spraying, cultivating, driving around with wagons, etc. Keep the trees far enough away from the boundary fences, and never plant nearer than forty feet to a thick wood or windbreak.

Dig a hole large enough to accommodate all the roots without bending any of them, and deep enough to permit the tree to stand slightly deeper than it was in the nursery row. After some of the fine surface soil has been scattered in the bottom, place the tree which has been previously well dipped in a thin mud, in the hole; carefully spread out all the roots and cover with a few inches of the top soil, pressing this firmly around the roots with the feet. If the soil is dry, slowly pour in four or five quarts of water. Finish filling the hole with soil and tramp down again. It is well to put a mulch of straw manure around each tree to partially prevent the evaporation of the moisture. The main point in planting is to take enough time to "do a good job." It is cheaper in the end to spend plenty of time in planting than to have to reset because of carelessness in planting. Manure should never come in contact with the roots of the tree, but put a good supply on top of the ground after the tree is planted. The rain on this will leach it and properly supply the necessary fertilizer for the tree.

CULTURE The orchard should be kept free from grass and weeds, and no crops should be sown in it except those which do not exhaust the soil. Cultivate well in the early part of the summer and late fall.

PRUNING If trees of bearing age do not bear fruit, it is well to prune such trees slightly during July or early in August. Some of the small limbs may be cut out or the ends of the outer branches may be trimmed back some by cutting off. This will help the. buds to form for next year's crop of fruit.

\section{DWARF APPLE Dwarf apples are especially to be desired for} the city lot where space is limited, since they may be trained along the fence, or along the side of a building. The same general principles apply to the planting of Dwarf Apples as to Standards. Its favorable soil is a strong loam of limestone nature. A deep, strong, gravelly, clayey loam, or a strong, sandy loam or a gravelly sub-soil, produces the greatest crops and the highest flavored fruits as well as the longest lived trees.

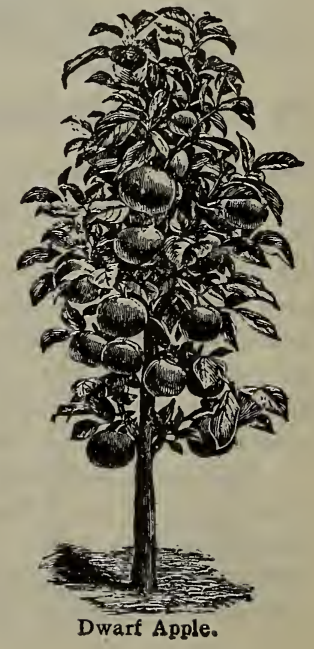


- almost any soil, but will do best on a high elevation, provided the subsoil is not too wet. Wherever this is the case the ground should be thoroughly under-drained. In very poor soil a heavy top dressing of manure in the fall will be of advantage. Standard pear should be planted twenty feet apart each way.

\section{DWARF PEAR}

Will thrive on the same kind of soil and under the same treatment as the Standard pear. At the time of planting, and each spring thereafter, they should be thoroughly pruned, shortening the preceding year's growth about one-half, aiming to form a round well proportioned head. Dwarf pears should be planţed from sixteen to eighteen feet apart.

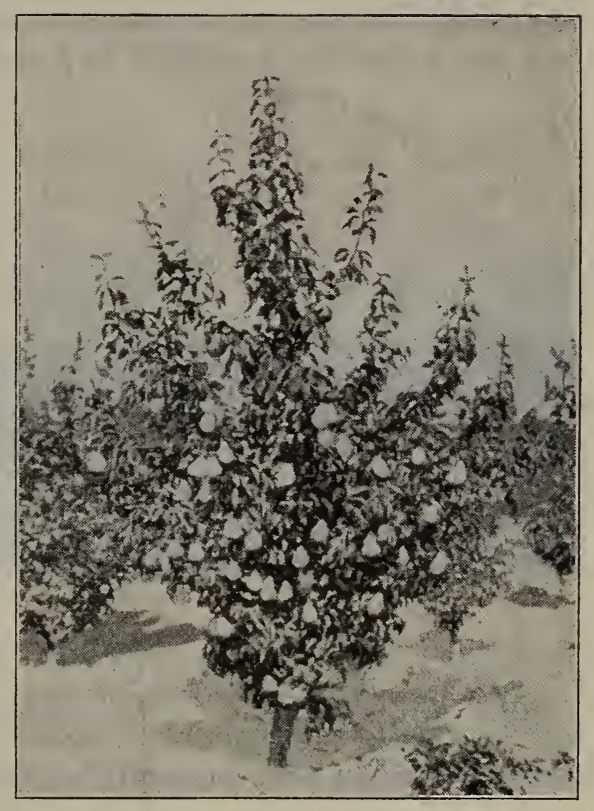

Dwarf Pear.

\section{FALL AND WINTER PEARS}

Neither Standards nor Dwarfs, should ever be allowed to ripen on the tree. In order to have the highest flavored fruits they should be gathered about ten days before ripe, and stored in a cool, dark place. Winter pears should be picked and stored before the heavy frosts.

In a climate rather cold for the pear or on a cold soil, it is well to plant on a southern slope, but in the middle states or warmer soils a southern exposure is not as good as colder ones.

CHERRY

The soil best adapted to cherries is a light loam or a sandy subsoil, although they will also do well in any situation that is well drained. Cherry trees are prone to grow too fast, splitting the bark on trunk or limbs and doing other damage. For this reason and because the fruit ripens early, cultivation should not continue after the first of June.

Never use much mulch under the trees, nor much if any stable manure. Nitrate of soda or any fertilizer containing much nitrate is liable to do more harm than good. This, of course, depends upon the soil. In general, cherries will thrive best when the ground is seeded to grass and kept this way, except about a foot around each tree. Here the ground should be dug up so the grass will not grow thick around the trees forming a harbor for mice. They are very apt to gnaw the bark and spoil the tree.

The less cherry trees are pruned the better for them. It is necessary to cut back the trees at the start and shape the head while growing. Sour varieties of cherries are free from insects and root diseases. 

loam, then a light, thin, sandy soil; the poorest being heavy, compact, clay soil.

Peaches must be cultivated. The soil must receive such treatment as will enable it to provide enough

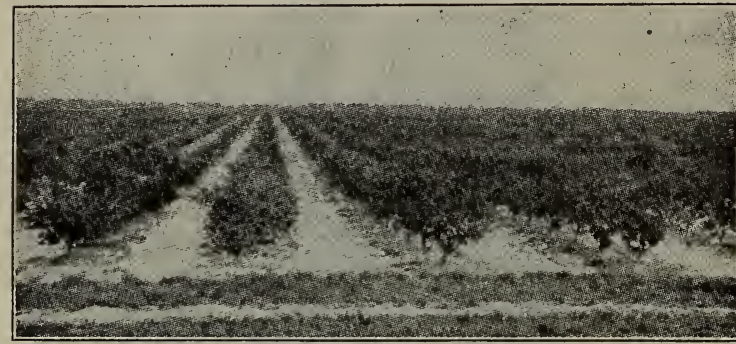

Well Cultivated Peach Orchard. moisture, sufficient available plant food, and earth fine enough to supply food for the roots. The time to begin cultivating is a year or two before the trees are planted. All that has been said about apple trees will apply to peach trees. Bearing orchards should not be plowed in the spring, until after the blossoms have dropped.

To obtain the best results from the peach orchard a few points are to be remenbered. First, keep the ground clean and mellow; second, keep the heads low (the trunk should not exceed two to three feet in height); third, prune early in spring, shortening the shoots of the previous year's growth.

Cut weak shoots back, about one-half, and strong ones about one-third; but see that there is left a sufficient supply of fruit buds. Sickly and superfluous branches should be cut out altogether. The fruit is born on branches of last season's growth, hence the necessity of keeping up a good supply of vigorous annual shoots all over the tree.

Peaches should be planted from sixteen to eighteen feet apart in the row. If a heavy mulch is placed about the trees after the ground is frozen, it will retard them in the early spring and often insure a crop of peaches.

\section{PLUMS \\ Are found to be more vigorous, healthy and productive in a clay loam, or heavy loam, than in a light soil, although the Japanese varieties thrive on lighter soils than would} be required by the other species.

The work to be done on a plum orchard is much the same as with the cherry, peach or apple. All plums must be pruned, though some kinds require more pruning than others. Nearly all kinds require tip pinching. Fruit is born on wood two or more years old. Keep the head open so the light can get in, and see that the bearing wood is cut back far enough, so that after a reasonable amount of trimming is done, it will prevent the trees from breaking with their load of fruit.

The worst enemy of the plum is the curculio. It can only be exterminated by bumping the tree and killing it when it falls on the canvas which has previously been spread under the tree.

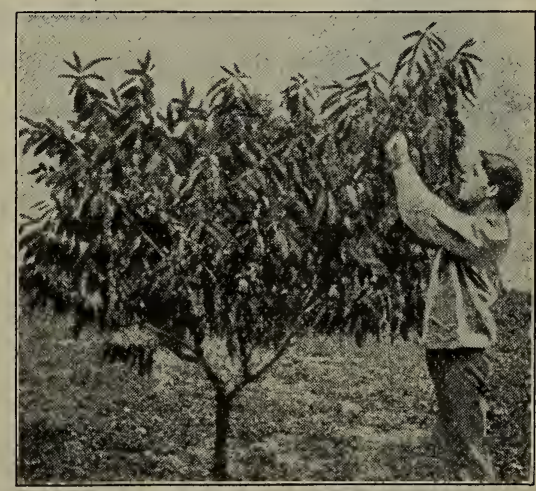

Tip Pruning in Summer. 


\section{QUINCES}

Quince trees will grow well in almost any soil, but succeed best iri a heavy, clay loam. The average hillside or top is too dry for best results.' Underdrain a good, damp soil and it will grow fine quinces, both trees and fruit. The roots lie close to the surface, so do not cultivate deeply.

Plant ten to twelve feet apart, and prune so as to have short trunks and round, shapely, wellbranched heads. Fruit is born on shoots of the same year's growth, which grow from wood at least two years old and pruned accordingly.

\section{GRAPES Are grown in all parts of the world, north} and south, and seem to thrive equally as well in one place as another. The kind of soil makes little difference.

Before planting is done the ground should be worked even more thoroughly and deeply than for a tree. Plow the land and use dynamite to dig the holes

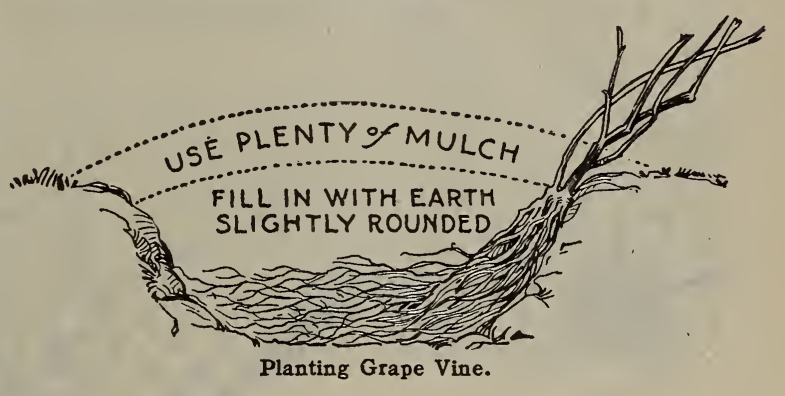
(if convenient). Have a clearance inside the hole of at least twenty inches. Roots should be laid

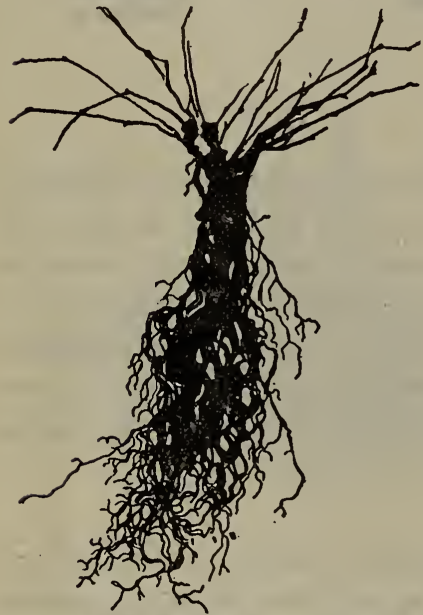
down and spread out-don't plant deeper than from eight to ten inches. "After-cultivation" should be complete and continuous, stopping each year only in time for the wood and fruit to ripen early in the fall.

The pruning of grape vines needs to be studied carefully to accomplish good results. Grapes are born on new wood and these shoots spring from buds or wood of last year's growth.

When a new vine which has grown one summer is started, all the shoots should be cut off during the next winter. Cut off all branches except three or four, and cut these back to two or three buds each, because each bud will average two branches. This principle holds good with any vine, no matter how old it is.

\section{Grape Before Pruning for Planting.}

\section{STRAWBERRY PLANTING}

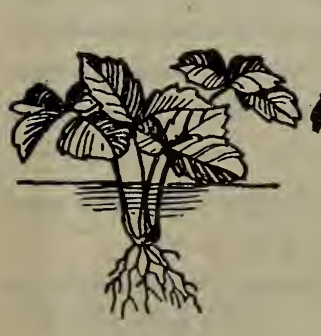

Too Deep.

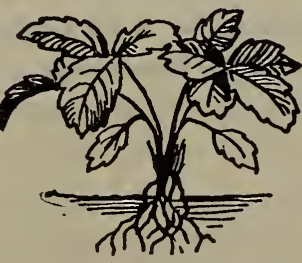

Too Shallow.

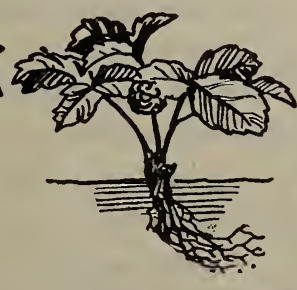

Too Cramped.

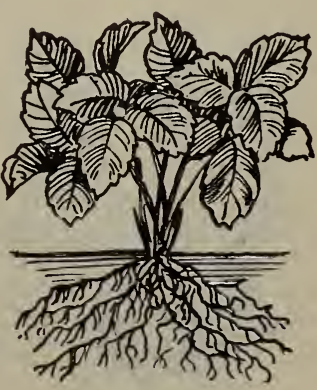

Right Way.

STRAWBERRIES

Will do well on almost any soil, but the richer the land the better the berries. The essential points are to have the soil fine and loose. Strawberries are naturally shallow-rooted plants and must be encouraged continually to send 
their roots deeper in order to be sure of a supply of moisture and to feed in a soil of even temperature. See that no soil is allowed to remain in the crown of the plant.

Strawberries for garden culture should be planted one foot apart in the row, with rows three feet apart. Spring is the proper time to plant. Mulching strawberries is done to keep the soil moist and cool in summer, to protect the berries from mud and dirt when ripe, and to protect the plants in winter. The winter protection need not be put on until after the ground freezes.

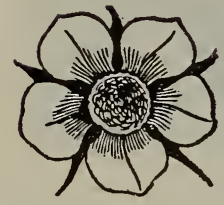

Imperfect or Pistillate

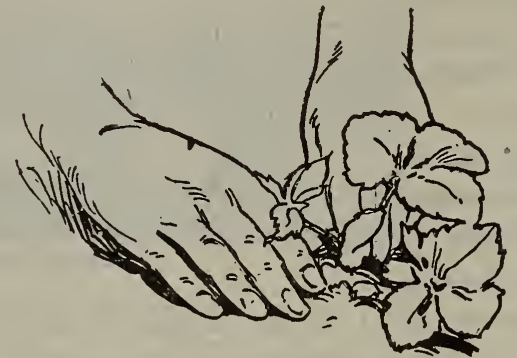

Firming Soll Around Roots.

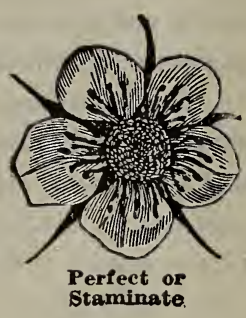

Trming Soll Around Roots.

Strawberry flowers may be either perfect or imperfect and the nature of the flower is characteristic of the variety. In some kinds the flower is perfect, that is, it has both pistils and stamens, so is self-fertile. In others it is pistilate, producing no pollen, and requiring a pollen bearing variety to pollinate it. The perfect flowered varieties differ greatly in the amount of pollen they produce. Some, as the Crescent and the Glen Mary, bear so few stamens that they are practically pistillate or sterile. Any variety will fertilize any other variety if it bears sufficient pollen and if the two kinds bloom at the same time. When planting pistillate varieties, every third row should be a pollen bearing kind.

\section{CURRANTS}

Planted in the garden should be four feet apart and may be mulched with the soil the larger the berries. The same general instructions for planting trees will apply to currants.

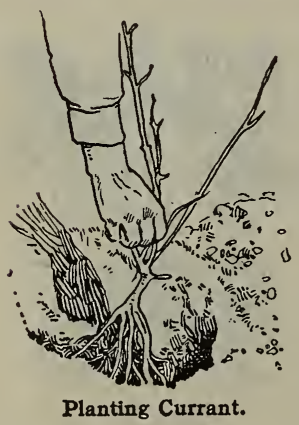

Pruning is simple but important. Fruit is borne on both young and old wood, but the best is at the base of one-year-old shoots. The younger the wood, the finer the berries, but a fair supply of old wood must be left to insure productiveness. From three to five stems is advisable and these should be frequently renewed. No wood over three years old should be allowed to remain.

Currant bushes may be kept in bearing for many years with good care, liberal feeding and the continuous renewing of the wood.

This pruning may be done in October or November, or just before the growth commences in the spring. 
generally considered best for the raspberry, yet the plants do well on a light, or even sandy loam, and on such soils the fruit will ripen some days earlier. The first summer only two or three canes should be allowed to grow from the root. In midsummer when the canes have reached a height of about two feet, the top should be pinched off with the thumb and finger, as this will cause the canes to throw out laterals.

The bushes may be trimmed in the fall, all the surplus suckers and old fruit canes taken out, and the suckers that are left for the next year's crop, cut back, within two and a half feet of the ground. This trimming out of old suckers, etc., should be repeated year after year. Mulching is a great advantage to both raspberries and blackberries.

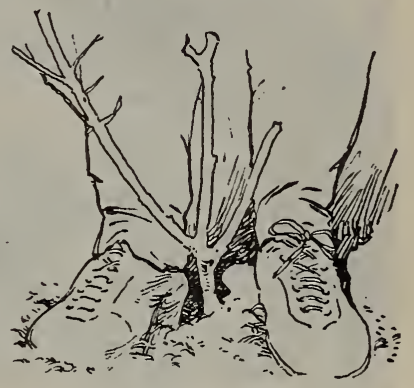

Firming Dirt Around Root.

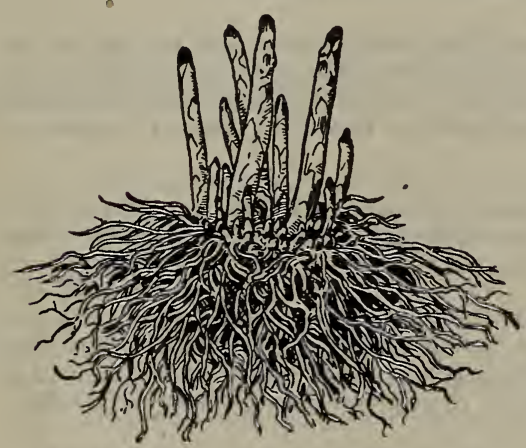

Asparagus Root Spread Out Ready to Plant. i

ASPARAGUS Is easily grown. A row 75 to 100 feet long, or its equivalent, will supply a small family with all the shoots it needs, and as the plantation is a permanent one, it should be placed where it will not be in the way when the rest of the garden is plowed.

For success, the soil in which asparagus roots are planted should be warm and well drained, yet moist and rich. Set the roots in the trenches six to ten inches deep and cover with only a few inches of soil. As the plants grow the soil can be levelled in. The ground should be thoroughly cultivated all summer and until late fall, when a heavy mulch of manure should be given. The food in the manure will leach into the soil all winter, and in the spring the rest can be worked into the ground. Cut tops off before seeds begin to ripen.

Asparag:' may be had any time during the winter if strong four-year-old roots are dug in the fall and stored in a cold place until wanted. They are then covered with a few inches of soil in a hotbed or greenhouse and kept very warm. In two weeks the shoots will be several inches long and cuttings may be made for a month.

\section{RHUBARB}

Thrives in a deep, rich soil, but it is such a strong, vigorous growing plant that it will do fairly well almost anywhere. Set the roots so that the crowns will be about an inch below the surface. It is a gross feeder, and the more manure supplied the larger and finer the yield.

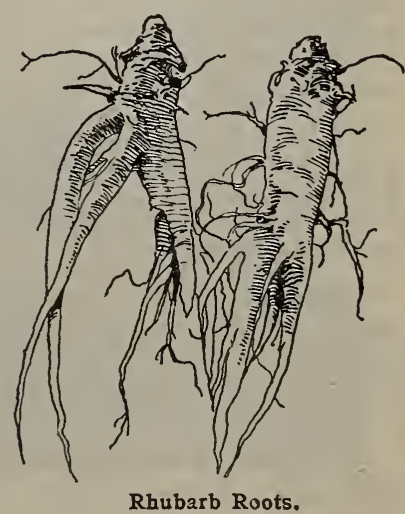




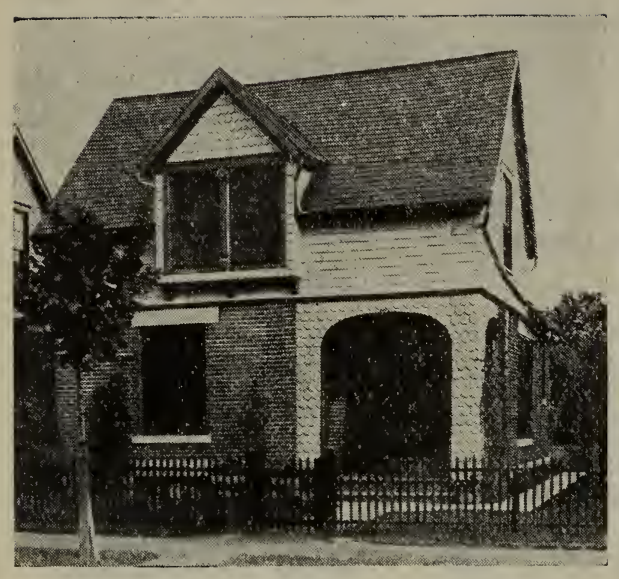

A House.

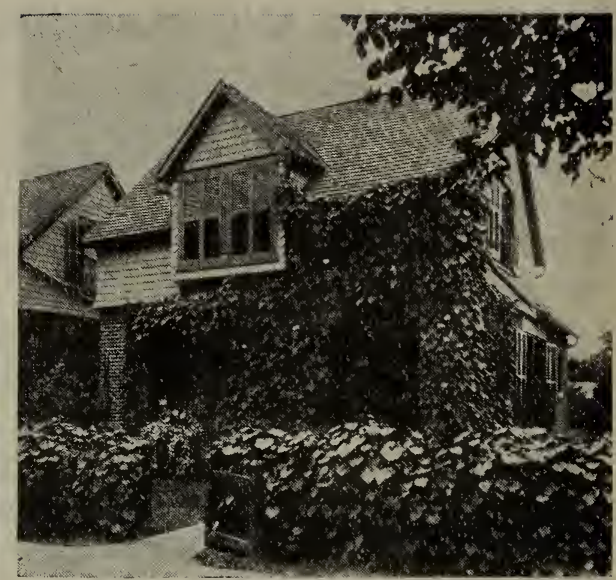

A Home.

\section{ORNAMENTAL SHADE TREES.}

\section{I.ANDSCAPE PLANTING.}

Houses and other buildings are not natural to the earth's surface and do not appear happy and at ease unless they have what the landscape architect calls a "setting.:- No matter how fine the material or how beautiful the lines of the house may be, it is not pleasing to look upon unless it appears as part of the land scape.

The buildings and grounds should be a picture, the house, of course, should be the central figure but the surroundings should all lead up to it and harmonize with it. A house properly "set looks homelike and comfortable.

The foliage of trees and shrubs is indispensible as a background or frame to the picture which is to be created. Everything - the lay of the land, the shape, the size, the color of the house, all must be considered and complete working plans made before proceeding. It is impossible to make any set rule that will suit all places. In fact, no rule will apply to any two places. The individuality of the place must be preserved.

Trees make the sky-line an important feature. They are often invaluable as wind-breaks, and they supply shade and retain moisture-conditions which are essential to the life of some of our choicest flowers.

Some of the trees are noteworthy for their profusion of bloom to such an extent as to almost hide the branches and young leaves. Among these are the cherry and plum, including the varieties that have come to us from Japan; the English Hawthorne with its array of American cousins; and all varieties of Crab Apples and flowering peaches. The flowering Dogwood is another tree noted, along with the Red Bud, for its abundance of bloom. Some of the Willows are especially attractive when planted near a bog garden, their catkins and bright colored bark, oftimes making the flrst announcement of spring.

Among the larger sized trees noted for their bloom are the Lindens, Locusts, Catalpa, Horse Chestnut, and Red Maple, the two first named being extremely fragrant. The blooms of the Norway and Soft Maples are also worthy of mention, althouch not so richly colored as the Red Maple. The dark green foliage of the Tulip tree is almost so dense as to hide the inconspicuous flowers, although they are worthy of attention.

There are other ornamental trees which do not attract attention by their bloom, but which have charms all their own. Some of our native trees such as the sturdy oak, in its many varieties; the stately American elm, which unfuris its branches in such majesty that it seems to tower above its neighbors; the sycamore trees with their large. light green foliage are well adapted to city planting for they are little affected by the smoke. The white bark of the sycamore is very attractive in winter.

Sometimes a weeping tree is highly effective when rightly planted on a lawn. One of the choicest of all these is the weeping birch. This tree has many attractive characteristics, which combine to make it one of rare beauty. 


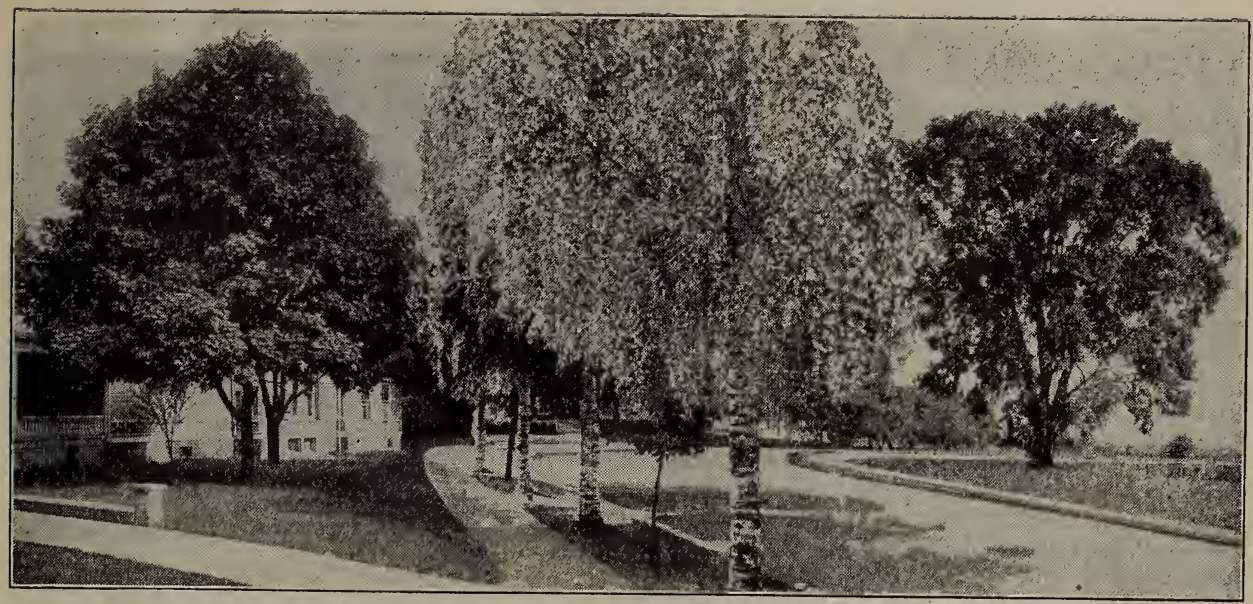

Maple.

White Birch.

Elm

For Lawn and Street Planting.

Another well-known weeping tree is the Camperdown Elm which, when well grown, will form an enclosure twenty or more feet in diameter. Tea's Weeping Mulberry, Weir's Cut Leaf Maple and some of the Willows are very attractıve and lend a particular charm to any spot that has been well planned.

The leaves of our common trees present a wonderfully varied assortment of greens that is very pleasing, but where a bit of other coloring is desired there are a few trees which may be well considered. The best of these are the Purple Leaf Maple, Scarlet Oak and Purple Leaf Beech, but care must be taken not to use too many of these abnormally colored leaves.

All deciduous shade trees may be planted in the late fall after the trees are fully matured, or in the early spring as soon as the frost is out of the ground. The hole in which the tree is to be planted should be considerably larger than the space occupied by the roots at the time of planting. The ends of the roots should be cut smooth and the space between filled in with good, rich soil, which should be carefully pounded down. Before the hole is completely filled, especially where the soil is light or sandy, a good wetting is useful in settling and packing the ground. It is usually well to cut off about two-thirds of last year's growth of branches. Do not disfigure the tree by cutting off large limbs, or topping it.

It is always best not to have a great variety of trees on a lawn. When one variety of tree predominates, the garden or lawn will have a distinctive feature all its own.

Trees not only furnish a background for the shrubs and flowers, but they make a boundary for the sky. It is desirable to have a large sky space and this space should be as informal in shape as the clouds themselves. Trees should be chosen with regard to the size of the garden. For a small garden only shrubs should be used as a boundary or perhaps one tree or group of trees on the north side. For a large garden, trees may sometimes be used on all sides, as there will be plenty of space for sunshine anyway. The outline may be varied by using groups of various kinds of trees, so that it may be irregular and produce a most pleasing effect. It is well if the trees can be planted a year or two in advance of the shrubs and perennials. The border of woody growth, varying from low shrubs to high trees, furnishes a frame or setting for flowers, shielding the shade-loving ferns and other shadeloving flowers from the sun in one place, giving the flowers the advantage of his rays in another, and protecting the whole from the sweep of the wind. Remember. the desired effects cannot be realized in one or two years.

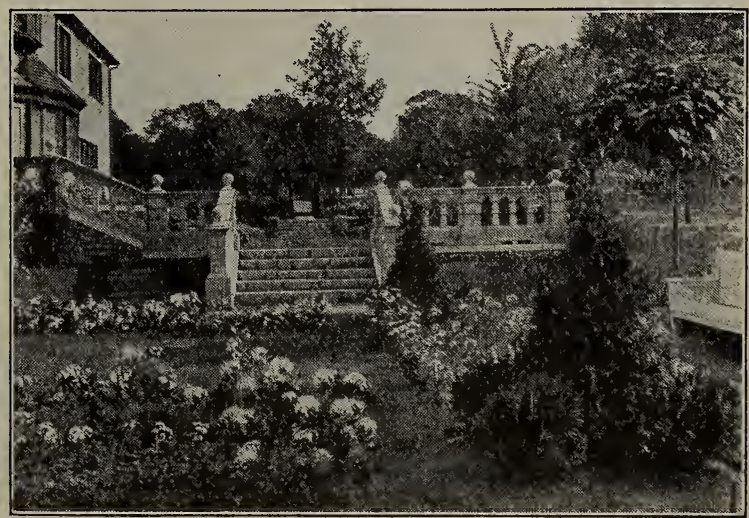

Well Planned Grounds in Keeping with House. 


\section{EVERGREENS No home}

whether lawn or garden, is quite complete without at least a few of the cone bearing Evergreens. The winter landscape would be dreary and monotonous, indeed, if there were no trees of this kind.

It is well known that the healthy growth of the conifers depends more upon the soil than climatic conditions.

The best soil for Evergreens is a sandy loam of good texture. Lacking this, the soil should be of good depth and well drained. The only conifers suitable to wet locations are the natural swamp lovers, of which two of the most beautiful specimens are the

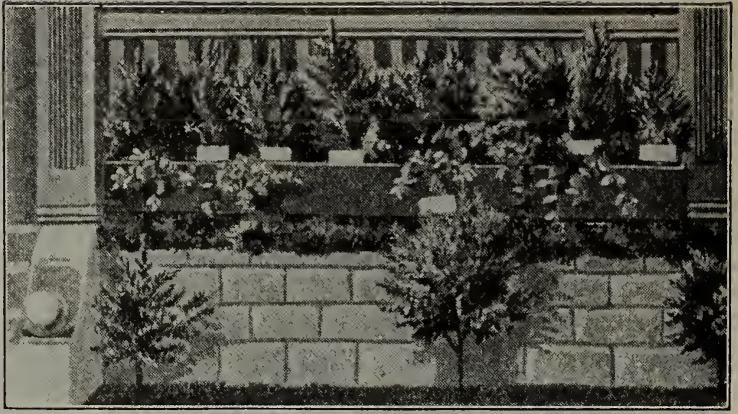

Porch Box of Evergreens for Winter Effect. long-leaf Pine and bald Cypress.

There seems to be no universal "best" time for planting Evergreens, but on account of the habits of growth the months of April, August and September are generally preferred. Which of these times is best, depends entirely upon the local conditions of moisture, not only in the soil, but in the air.

When buying Evergreens it is always best to have the trees balled so the soil will not fall from the roots. The holes in which the Evergreens are to be planted should be at least three times as large as the ball around the specimen to be planted and eight inches or more deeper. By carrying out this idea all the soil around the roots will have been thoroughly loosened or cultivated. When the tree is placed in the hole the ball of earth should be broken up. Fill the hole partly up with loam (as described for other trees) then almost fill the hole with water. Let this settle and fill in with remainder of the dirt, firming well around the trees. Use plenty of mulching of well rotted compost.

There is a large variety of Evergreens-some long lived, some short lived, some tall, some dwarf, some dark green and some light green. Among later introductions are the golden, the blue, and the pendulous forms, each one has its strong points, making it particularly desirable for certain locations.

(Lists of Evergreens for different purposes will be found after page 24 in this book.)

\section{BROAD-LEAVED EVERGREENS}

The broad leaved Evergreens stand in a class entirely alone. They require much mous evaporating surface in winter when deciduous trees and shrubs have none at all. Consequently, if the sun strikes these broad leaved Evergreens during a thaw in the winter, the leaves have to transpire as usual, but the roots, being frozen, cannot supply moisture to the leaves as fast as they need it, to replace what they are giving off. That is the chief reason why so many rhododendrons die.

There are a few rules to be remembered in regard to broad leaved Evergreens:-

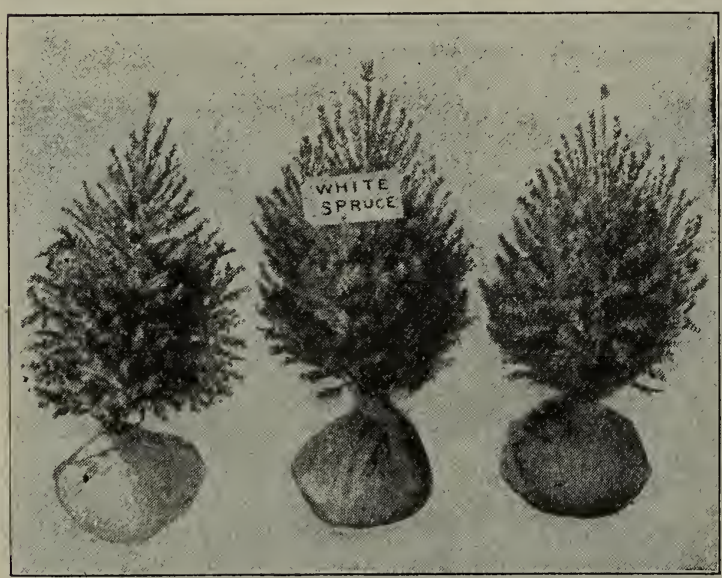

Evergreens Balled Ready to Pack in Boxes for Shipment.
1. Plant broad leaved Evergreens in a partially shaded position where they will be protected from winter winds and sunshine.

2. Prepare the soil with the greatest possible care.

3. Give perfect drainage and, if a limestone soil, treat with sulphate of magnesia.

4. Mulch with a foot of litter, summer and winter, for the Broad-leaved Evergreens are usually surface feeders and always sensitive to drought.

The ideal cultural conditions for all Broad-leaved Evergreens are these:-

A light, rich loam-one having for nearly a third of its bulk well ripened leaf mold, or very thoroughly rotted manure; at least two feet or more of this mixture; more would be better.

The best broad leaved Evergreens for this section of the country are the Mahonia Aquifolia, American Holly and Boxwood. 


\section{SHRUBS}

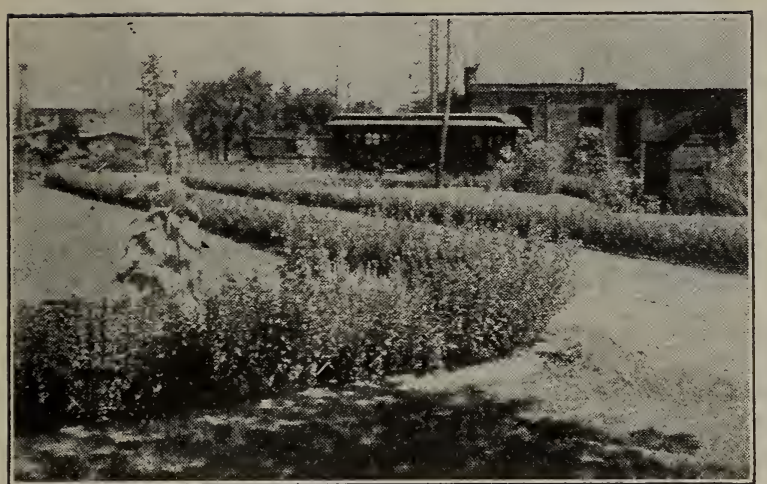

Effective Planting Replacing Weeds and Trash of a Few Years Ago.
A look at Nature will reveal the fact that there is always a greater or less amount of shrubbery to be found in any grove where Nature has not been restricted. It is generally conceded that a lawn or park is not quite complete without a certain amount of shrubbery and perennials being planted. By careful study of the surroundings of a place, certain features may be more effectively brought into prominence, unsightly objects screened and a greater amount of comfort and coziness secured by a judicious arrangementand planting of shrubsand perennials.

There can be no general plan laid down for all places, each place being a law unto itself.

(See top of page 16 for plan suggestion.)

The first thing to be done is to study well the plot of ground under consideration; its slope, the relation it has to the surroundings, the kind of soil, the temperature and the buildings upon it.

Next study well the kind of plants desired, and, of these, select those that are best adapted to the conditions where they are to grow. (List of plants for different locations following pages 28.)

All that is necessary in planting the shrubbery border, is to plow or dig the soil up to a depth of one or two feet, give a liberal supply of manure-preferably from a cow stable-plant in the fall after the stock has thoroughly ripened, or early enough in the spring for them to feel at home before the hot, dry weather of summer. Having received the shrubs from the nursery, plant them justas quickly as possible, so that the roots may not be exposed to the sun one minute longer than necessary. Set as deep, or a little deeper, than they were were in the nursery row and about three feet apart. If closer than this they will look crowded, while if farther apart they will look lonely. In two years the branches will intermingle, and probably in five or six years it may be necessary to remove every other one of the shrubs and plant them in some other place.

When planted, trim back the branches to balance the loss of the roots. In the autumn it is well to give the shrubbery border a dressing of manure.

Avoid isolated specimens. A better effect will be obtained by grouping them and planting the tall varieties in the background, using the lower and dwarf varieties in the front. Do not plant shrubs in straight lines. It is well in outlining the border to have deep bays which will give a greater distance and also carry with them the idea of a mysterious passage to something beyond.

Shrubs may be used as a screen to hide unsightly objects. A barrier of living green makes any unpleasant object practically non-existant whether the space be large or small. If privacy is desired the shrubbery border may be so arranged as to almost completely exclude the outside world and yet allow views which will add a great charm to the grounds.

, One of the most important points to be kept in mind is to harmonize the buildings with the shrubbery and trees. The object desired in the home grounds is to give the house and other buildings, which are not natural to the ground, a perfectly comfortably setting, so they will look cozy and homelike. This requires a careful planting of shrubs and vines around the walls of the house, so that it will have something tieing it to the ground, as it were. Here, again, beware of shutting yourself in, while shutting out the public. The planting along the side of the house effectively breaks the line between the house and ground. Here, as in the border, avoid straight lines. Do not plant the tall growing plants in front of the windows. If planting for winter effect as well as summer, there are many forms of evergreens, especially the dwarf varieties that can be used in the beds in front of the walls. All shapes and sizes may be had to suit the style of architecture.

The varieties of shrubs are so many that the amateur may well be puzzled when it comes to selecting what is needed. A succession of bloom may be had for about eight months of the year, while during the other four months the red, yellow and green twigs of some shrubs and bright berries of others will tend to liven the dreary landscape.

The commonest mistake of all is to have too great a variety of shrubs on a small lawn. It is far more effective to have a clump or mass of one kind of bloom than to have single specimens.

Another mistake that is frequently made is to use too many plants with highly colored leaves, such as Purple Leaved Plum, variegated or Golden Leaved Elder, etc., or too many weeping trees.

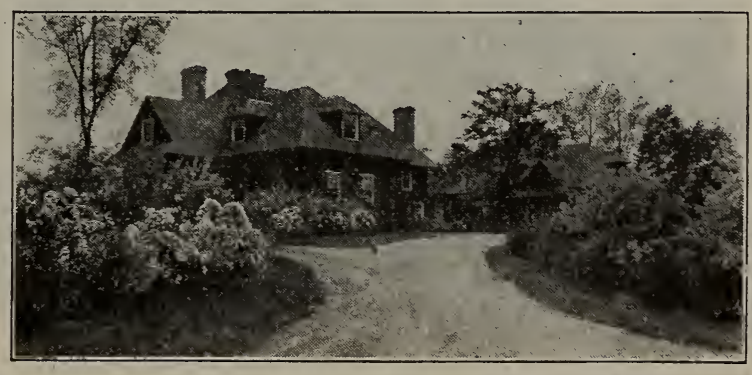

Well Planned Country Horne Producing Natural Effects. 
PLAN FOR SMALL NARROW LAWN

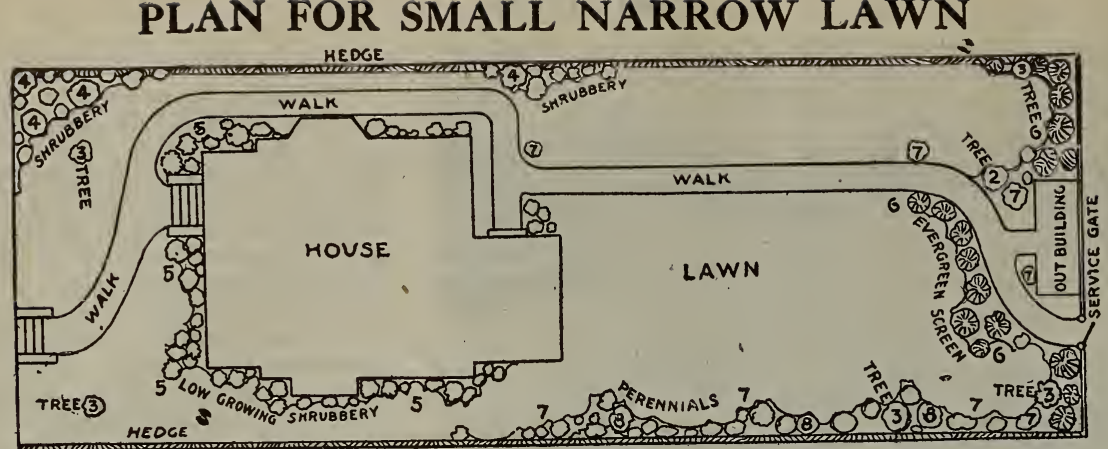

Varieties or kind of plants may be selected for this planting from classified list in back of book.

\section{VINES}

Vines probably lend themselves to a greater variecy of uses than any other plant, and offer a splendid opportunity to anyone with a little taste and ingenuity, to carry out many schemes of his own devising. Their chief value lies in their ability to quickly cover trellises, pergolas, shut from view unsightly objects, such as out-bujldings, laundry yards, shading porches, etc. They aid greatly in harmonizing the house and the landscape, cover buildings and such objects as no other plants can, and break up the sharp contrast between building and ground.

Generally speaking, vines are better adapted for planting at the inner points than the outer, while shrubs should be placed by exactly the opposite rule. When planted at the inner angles they can climb upon both walls and partially conceal the inside corner line. When planted at a pergola it is sometimes wise to plant a different vine at each pillar, thus having a succession of bloom, instead of a great mass of flowers at one time and a monotonous appearance the rest of the season.

Climbers will not exhibit their best charms if trained in too stiff and formal a manner. They must, in whatever position planted, be allowed to grow untrammeled to a certain extent. Keep as far from the formal manner as possible. If expected to exhibit their best graces they must be allowed to grow uncontrolled.

All know the uses to which vines are most commonly put-that of covering walls, shading or screening porches and verandas and the covering of trellises and pergolas. Besides these uses, there are a few places, whether large or small, that offer opportunities for their growth in a more natural way that will add greatly to the charm of any garden. Perhaps a neglected shrubbery, undesirable in itself, will afford support for such easily grown vines as the Honeysuckles, Clematis Virginia or Clematis Flamula. An unsightly fence may be made a thing of beauty with climbing roses, honeysuckles or clematis paniculata. An old tree past its prime or half dead, will furnish a most excellent support for wistaria, trumpet creeper, aristochlia, or the common Virginia creeper, and produce a happy result.

Notice how Nature has decorated fence post, tree, bush and rock-pile with a luxuriant growth of vines. All vines require a trellis, or support, which should be made as inconspicuous as possible. Poultry netting is one of the best supports to be had, using the different sized mesh for different kinds of vines.

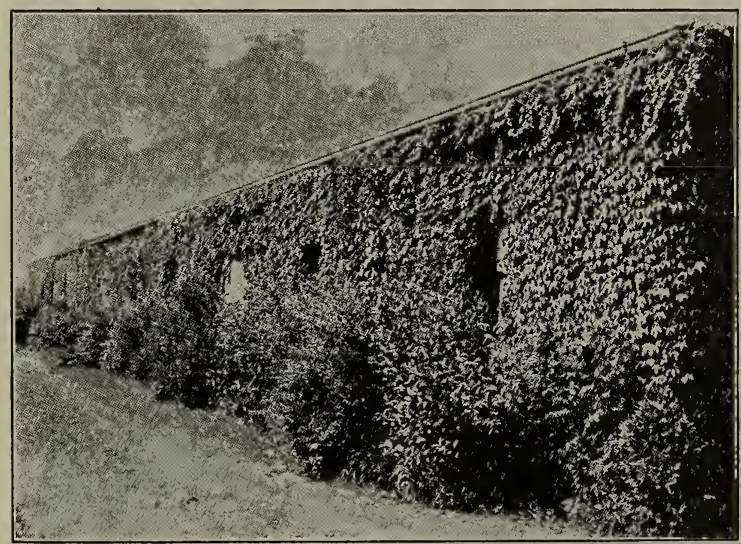

Boston Ivy Covering Stone or cement walls. Shrubbery along Base of Building.

\section{PLANTING VINES}

The same seasonal practice can be followed in planting vines as in other stock, but when necessary to plant in the fall, it is best to protect the vine during the winter with five or six inches of earth and then train it up in the spring.

Most vines are rank growers and require a liberal amount of plant food. For vines of all kinds, well rotted manure is to be preferred to commercial fertilizers. It is more lasting; it collects and stores moisture that er:courages root action, and finally there is very little danger of giving the plants too much and thereby injuring them. The best way to apply the manure so that the plants will get the most benefit from it, is by trenching or subsoiling; that is, by digging out a trench about two feet deep and putting some of the top soil in the bottom, then a layer of well rotted manure, another layer of soil, etc., until the trench is full; straighten out all roots as in tree planting. 


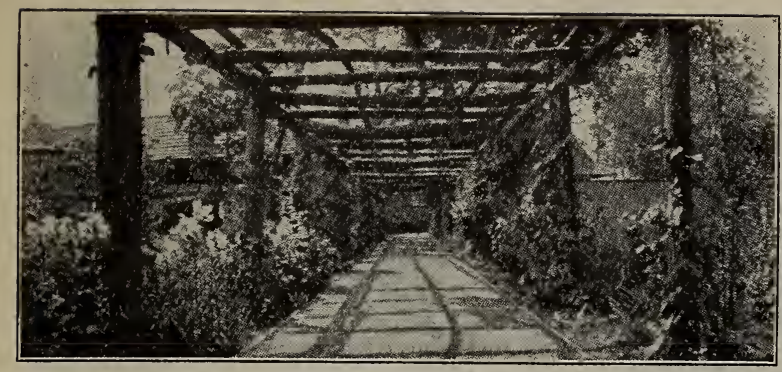

Pergola.
- Watering vines is one of the most important points in their growth. - If the season is dry, the plants should be watered at whatever season of the year they make their growth. This varies with the variety. When watering, soak the ground thoroughly and it will not be necessary to repeat the operation so of ten.

In selecting specimens, one should use well grown, two-year-old plants. The choice of plants depends upon the effects to be secured Where a permanent covering for a porch is desired the Akabia Quinata, a Japanese production, is one of the best. It is quite hardy and unfolds its leaves early in the spring, retains them late in the season, is free from worms and caterpillars, and is a rapid grower when once established.

The best known and most useful of the foliage vines are the Boston Ivy and Japanese Ivy. These are the most suitable for brick or stone walls, because of the disk-like tendrils on the young growths by which they hold on securely and are supported to any height. The Boston Ivy is perfectly hardy thrives in any aspect, north, south, east or west and succeeds as well in smoke and dirt of cities as in cleaner atmospheres. After once established, it needs no attention except cutting back where it encroaches on windows, doors, etc. The leaves appear early in the spring, showing beautiful tints of green and red-brown. In the autumn they turn bright gold and scarlet and are retained very late in the season.

The Virginia Creeper belongs to the same family, but does not hold so firmly to walls as the Boston Ivy (see illustration, page 16), trailing much more freely and being better adapted to covering boulders, banks and low walls. When possible, it is well to plant at the top of a wall and let it trail downward rather than climb upward. The leaves turn to bright colors in the fall and the blue berries are favorites of the birds. Neither of these vines have any insect enemies.

The Engish Ivy is the only distinctly evergreen vine that is suitable for high walls. It is particularly hardy as far north as New. York, but does better on a northern exposure, or where it will be protected from the sun in winter. The English Ivy is rather a slow grower but there is no other vine that surpasses it in beauty. In planting, treat as an evergreen shrub. Plant six or eight feet apart and supply them plentifully with water the first summer or until well established. This vine has few enemies.

Another evergreen vine that is worthy of a mure prominent place on the home grounds, is the Euonymus Japonica var. radicans. It is frequently seen in masses, used as a low shrub for covering bare spots and for this it is well adapted, but also possesses great merit as a true vine for walls, trees, rocks, etc. It clings as closely to a stone wall as the English Ivy, and the small, shiny, green leaves are about an inch across.

There is also a variety with variegated leaves that is very decorative. These vines are quite easy to establish when planted in early spring in rich soil.

Among the most useful of hardwood vines requiring support is the Chinese Wistaria (see illustration on page 18). When once established this vine makes a good growth, with but little care. Never prune until after the blooming season is passed, or the bloom stems will be removed. When the Wistaria is trained over a porch, the vine should be fastened across, so that the blossoms may drop gracefully into view.

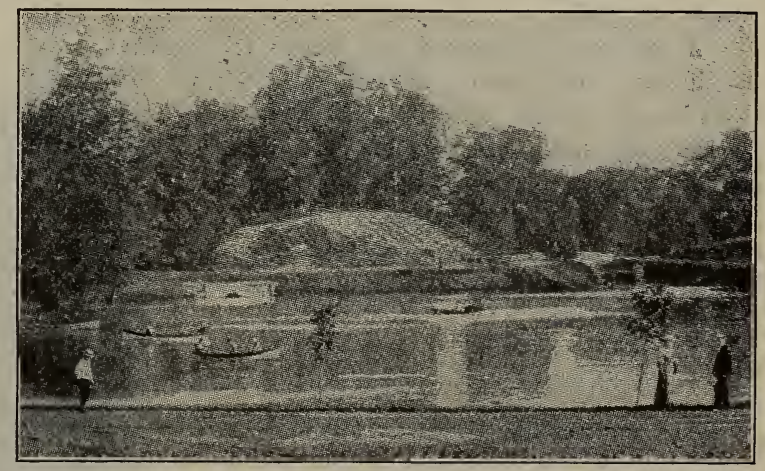

Barren Hillside, Beautified with Evergreen Honeysuckle, Glenmiller Park, Richmond, Ind. 


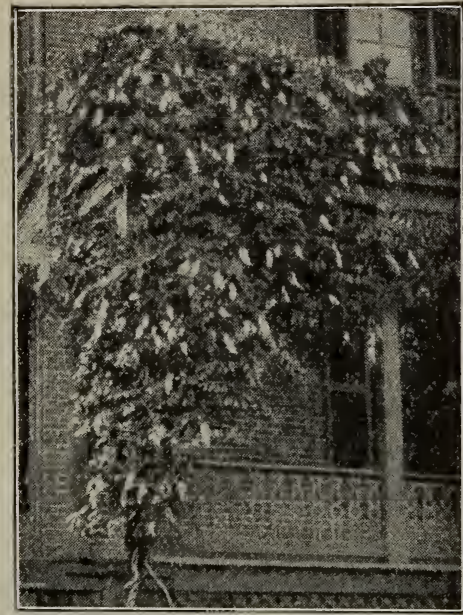

Wistaria Vine.

The Bignonia or Trumpet Creeper is also another hardwooded, fast growing vine that requires but little care and is almost self-supporting. It is perfectly hardy and a fast grower, soon covering an old tree, post, etc.

Several of the Clematises are excellent for screens or trellises or for draping on walls and pillars. The most generally grown for this purpose is the Clematis Paniculata. It is one of the very showiest of all vines, producing more flowers than any other in August. It is best adapted for trellis work, but wherever used needs a support of coarse-meshed wire to which it may cling. It is best to cut back the old growth very severely, as the flowers are produced on the current year's growth. Among other Clematises that are suitable for similar situations and extend the flowering season are Clematis Virginiana, Clematis Vitalba, Traveler's Joy, Clematis Coccinea and Clematis Flammula. Among the large flowered Clematis are the Jackmani, Madam Andre, Henrii, etc. These do not flower in such profusion as those of the former type and should be planted in the most prominent places.

For more aense shade, for covering walls and rougher portions of the garden, the Honeysuckles are superior to all else. They grow quickly, are not particular as to soil and produce an abundance of very fragrant flowers through a good part of the season. Though they are not particular as to soil, like any other plant they respond quickly to good treatment. When planting, it is well to dig out a good sized hole and fill in with a good quantity of rich soil, and the plants soon establish themselves. When once planted they require but little care and none of them except the Red Trumpet variety are subject to attack of insects or disease. Among the best are Hall's Japan Evergreen flowering in the fall. The one with variegated foliage as well as the one with reddish flowers blooms all summer.

While climbing roses are not vines in the true sense of the word, they are so easily tied and trained and are so very effective that they need to be so considered.

PERENNIALS. The old-time Perennials, with their improved cousins, are coming to be (A plant living more than two years) more widely known and planted with each year. No hardy border is quite complete without it being interplanted with some of these choice specimens, and the whole border filled with Perennials is a thing of beauty and a joy every day during the flowering season.

A very effective way of planting, especially when the space is long, is to use a large quantity of plants and a few varieties, whose blooming season follows each other in quick succession. It is a good idea to plant the whole border in small groups, so that the entire space is attractive with flowers of one kind, and perhaps one or two colors. If this plan is followed, the border cannot present a whole mass of bloom, but there are pleasant changes almost every week during the season.

The preparation of a Perennial bed should be very thorough, especially as the soil cannot be well tended or much enriched afterward. If the subsoil does not permit sufficient under-drainage to prevent water staying on the surface, then under-drainage to the depth of at least two and a half feet will be necessary.

A first-class Perennial bed, suited to sustain a large variety of plants in vigorous growth, should have the ground made loose to a depth of at least two feet. A satisfactory method is to throw off the top soil, then dig over the subsoil and mix with it a liberal amount of manure and some bone and wood ashes. If the soil is a stiff clay, an application of about two inches of screened coal ashes or sand worked into the soil will keep it loose.

The top, if possible, should be good rich loam, well mixed with well rotted manure from the cow barn and put in a fine, pulverized condition. Keep the surface soil rich at all times, since many of the plants are shallow rooted and need a very mellow soil.

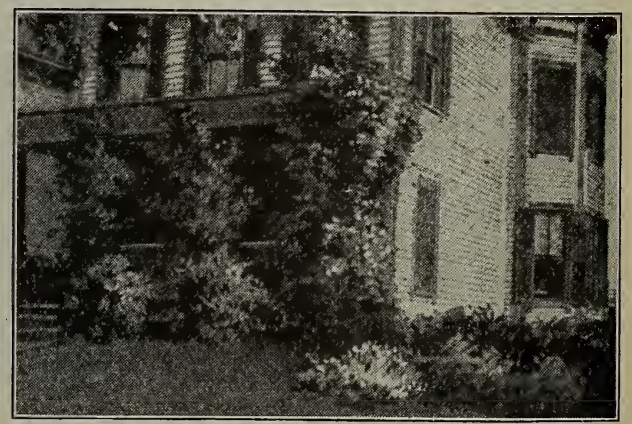

Vines and Shrubs Around Porch and Foundation of House. 


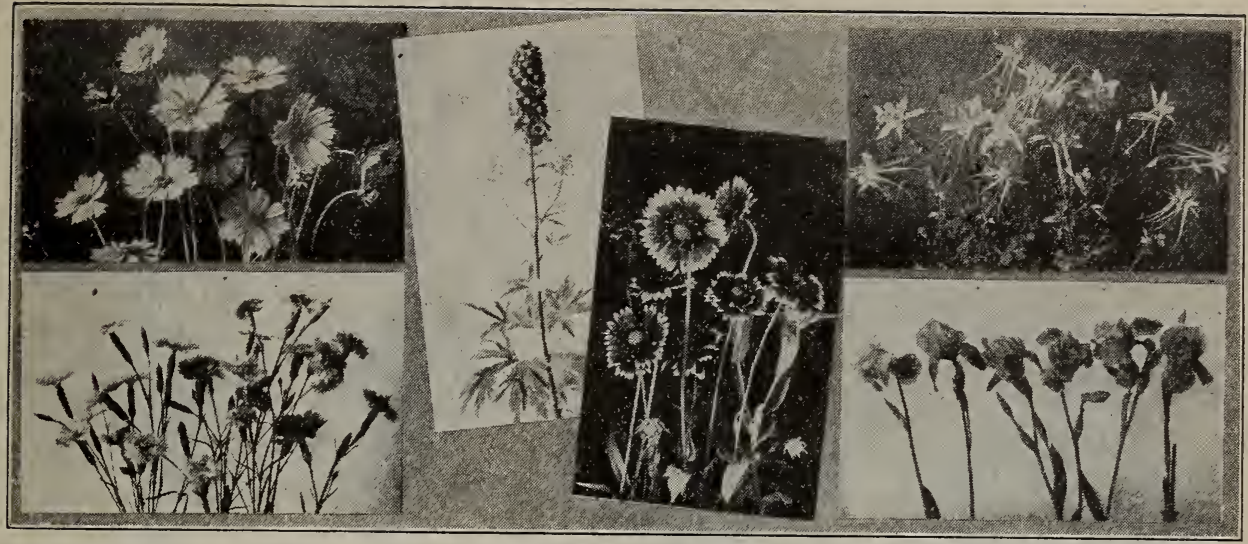

Coreopsis, Hardy Pinks, Larkspur, Galllardia, Columbine, Iris.

The English think nothing of making the Perennial bed at least four feet deep.

The same rule applies to the outline and location of the Perennial border as apply to the shrubbery border. Place the beds on the margin of the lawn, along walks or driveways near the house. A simple way to lay out these beds is to lay a rope or hose on the ground and arrange it in the form that is most pleasing to the eye, then mark the line by stakes or the spade. Do not let the curves be too narrow, as that will interfere with the cutting of the grass. The side bordering, a fence or lot line may be straight, unless the neighboring lot owners agree to decorate their lawns, so as to form one extended landscape view. Then the irregular outline may be carried out on both sides, thus seeming to extend the space owned by each.

An open, sunny situation, far away from the roots of trees (which rob the soil of moisture and food) is best for most Perennials.

When the plants are received from the nursery, unpack them at once. If the quantity be large the plants should be heeled in, in some shady spot, after having been well watered on both root and top. Be careful not to get the labels mixed. Plant at leisure, making the hole large enough to accommodate the roots when straightened out. Then half fill the hole with soil well firmed, after which water. When the water has disappeared, finish filling with dirt. If the plants wilt during the day it may be well to shade with a shingle or an inverted flower pot for a few days.

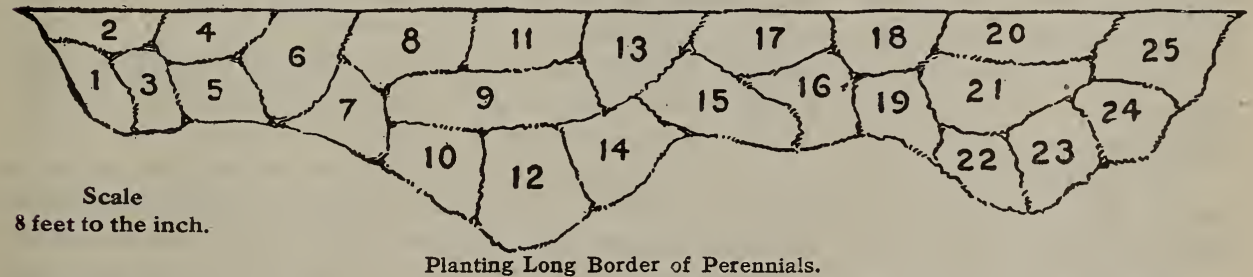

1-Five Shasta Daisiẻs.

2-Five Flags, Iris German.

3-Five Columbine-Aquilegia.

4-Six Foxglove, Digitalis.

5-Eight Speedwell-Veronica

6-Ten Rudbeckia Newmanii.

7-Eight Coreopsis Lanceolate.

, 8 -Six Hollyhocks.

9-Twelve Phlox, assorted.

10-Fifteen Sweet Williams. Dianthus Barbatus.

11-Six Kansas Gay Feather, Liatris

12-Seven Blanket Flower, Gaillardia.

13-Six Beards Tongue, Penstamon Barbatus.
14-Eight Chinese Bellflower, Platycodon Grandiflora.

15-Eight Cone Flower, Rudbeckia Purpurea.

16-Fifteen French Honeysuckle. Hedysarium coronarium.

17-Fifteen Golden Glow, Rudbeckia.

18-Three Treefoil, Desmodium Penduliflorum.

19-Three Potentilia.

20-Eight Marsh Mallow, Hibiscus Mehanii.

21-Eight Phlox White.

22-Eight Baby's Breath.

23-Ten Forget-Me-Not, Myosotis Palustris

24 -Twelve Pansy Viola:

25-Six Paeonies. 

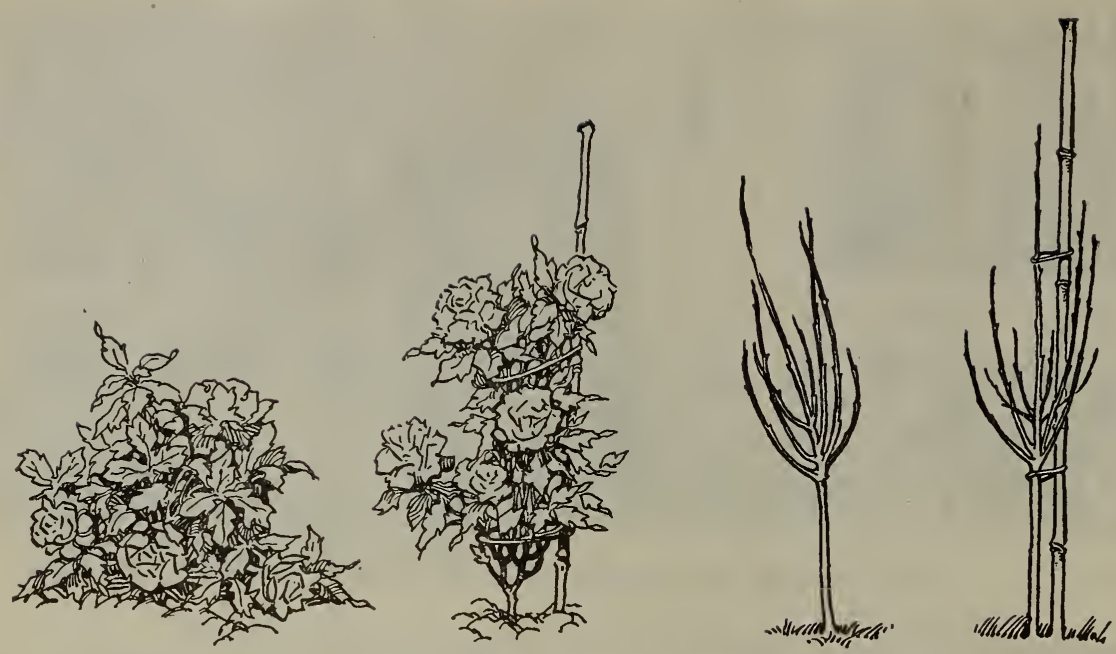

Trees and Plants Staked with Bamboo Sticks.

When tall plants are used, it is often well to stake them or they will be prostrate on the ground when blooming season appears. Slender bamboo sticks are excellent for this purpose.

\section{PERENNIALS FOR EARLY SPRING.}

It is an easy matter to have a mass of bloom during the summer months, but to possess plants yielding their lovliness before winter has hardly taken its departure, is indeed a luxury to be enjoyed.

There are some half dozen Perennials that gladden the heart during April and May and are more than ordinarily charming. The Hepatica-that exquisite little plant from the heart of the forestsucceeding so well in the sunny border or garden, heads the list for earliness of blossom, and what an individuality it has! No two clusters alike; all shades and sizes; some sending forth a dainty perfume like the violets. A closely planted bed of Hepaticas will radiate as much beauty as a bed of Crocuses and afford much more enjoyment. The Hepatica is easily transplanted at any time during the growing season.

Just before the beauty of the Hepatica has departed the Bloodroot breaks into flower and is the chief attraction for a week or so. The flowers are pure white with a heart of golden yellow. The bloodroots are very hardy and may be easily transplanted.

The Hardy Primrose begins to display its bright colored buds about the last of April, and lasts well into May. The Primroses with their wealth of color, or pure white blossoms, are always welcome. They are perfectly hardy if given a good covering of leaves in the fall.

The Rockcrest and Candytuft are two companion plants with a great profusion of pure white flowers. These are followed closely by the veritable carpet of pink or white of the Creeping Phlox, which is so easy of culture, extremely hardy and perfectly adaptable to planting in the sun or shade..

Beginning with the last of May there is such a wealth of varieties of Perennials that the question is, "What shall be planted?" There are Perennials for every location, whether sunny or shady, high or low, but to know how to make the happy selection is the point which puzzles.

The study of color effects is also one of interest and one that requires a pretty good knowledge of the plants. It is well to use white, gold, or a dull purplish hue to harmonize the strong colors. (To aid you, there are some lists of Perennials for every location near the back of this book.)

ROSES. Never before has the "Queen of Flowers" been so available to everyone, as now. ROSES. Other flowers may be "boomed" for a day, but their glory soon fades, and anotber comes forth to take its place, but the rose continues as the most prized flower of the garden.

The garden rose of today has been bred for the beauty of its plant form, as well as for the beauty of the flower. It is likewise being bred for health, hardiness, freedom and continuity of bloom. As a result, the hybridizers have produced some wonderful specimens, through all the beautiful shades of red, yellow, pink, crimson and pure white. 
The ideal site for a rose garden is a spot airy but sheltered (especially from the biting winds of winter), open to the influence of the sun, all day if possible, and quite free from the influence of large and growing trees. A southern exposure is best, but if this cannot be had, select a place that receives the morning sun. Never plant roses on the north side of a building, hedge or windbreak. Low ground is more subject to late frosts than the adjacent places only a few feet higher, and the late frosts are to be dreaded after the young shoots have started.

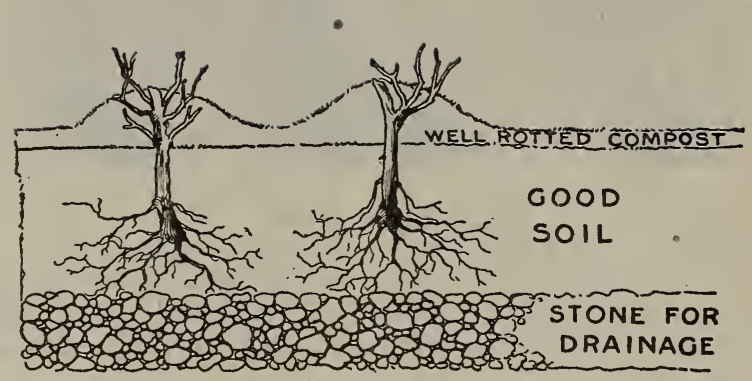

Cross Section of Prepared Rose Bed.

SOIL The best soil is a deep loam. Well drained ground is essential, and the site should never before have been used for roses; unless new soil has been substituted for the old.

Roses cannot live in soil that is wet. This objection can usually be avoided by digging out the bed to a depth of three feet and filling in one foot with boken stone, bricks, cinders, gravel or anything that will permit a free passage of water. If this does not answer, one must resort to tile drainage.

At least three months before planting, the soil for the beds should be dug to a depth of two feet and liberally enriched with well rotted manure (preferably with cow manure).

\section{TIME TO PLANT}

As a rule, spring planting of roses gives the most satisfactory results in the end. The Hybrid Perpetuals and Rugosas should be planted just as early as the soil is suitable. All others are best planted after April 20th, when the danger of sharp frosts has entirely passed.

When roses are unpacked, if they seem to be shriveled, soak them in water and bury them completely (cover up roots and branch with moist earth) in a trench, after which soak the ground with water. In a few days uncover and they will be found revived.

The first rule for planting is to wait for dry soil and select, if possible, a cloudy, calm day. The roses may be immersed in pails of water or dipped in mud, to prevent the roots from becoming dry while the planting is being done. They should be planted deeper than they were previously set, permitting the dirt to come up slightly higher than the previous mark.

Before planting, each plant should be examined and all broken roots cut off with a sharp knife. A hole large enough to accommodate all the roots (without crowding) should be made for each plant. On budded roses, the crown or point where the bud was inserted, should be placed two inches below the surface of the soil and all the roots spread out carefully, inclining downward a little. Cover the

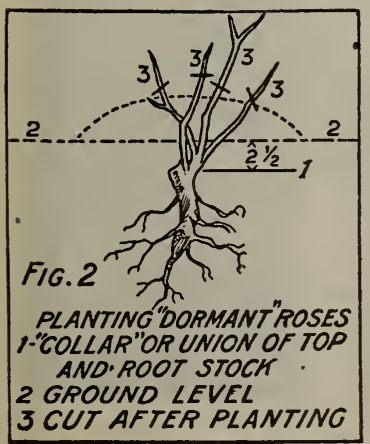

roots with fine soil, free from

fresh manure, water well, and when the water has disappeared fill in the remainder of the soil and pack firmly. This may be done by tramping around the plant. It is always well to add a mulch (a top dressing of coarse manure) for the winter months. In the spring this can be partly removed. Do not cultivate over three inches deep, as the roots come quite close to the surface and are likely to be injured.

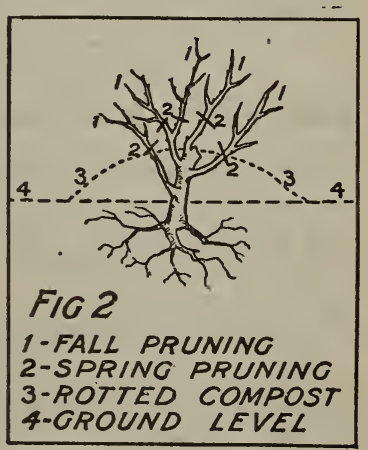




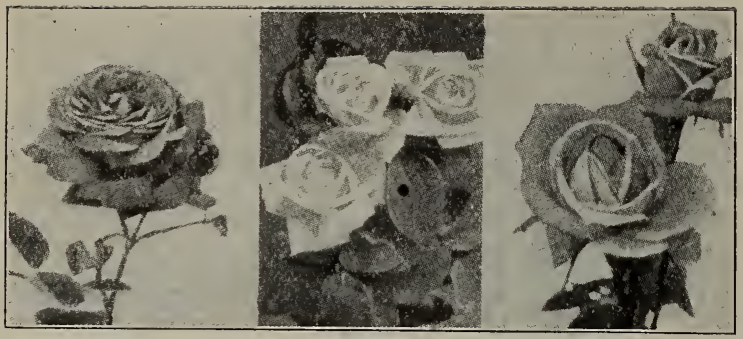

Roses Admired By All.

manưre. This is to enrich the soil and hold the moisture.

Throughout the entire season until the middle of July, frequent stirring of soil is necessary. Keep a sharplookout for suckers that shoot up from below the graft. As soon as these appear they should be removed. (Suckers are shoots that come up from below the bud or graft, and are, therefore, seedlings and will not have perfect flowers or will not be the kind desired.)

After the last cultivation has been given, apply a liberal mulch of cow

It is usually better to give the roses some protection during the winter months. A neat and effective way to accomplish this, is to place a twelve-inch poultry netting around the bed and fill with leaves. Evergreen boughs make a good protection, but are difficult to get at most places in any quantity.

PRUNING The pruning of hardy roses, climbers and non-climbers should be accomplished to grow in the spring. In pruning, cut out all the dead wood and weakest shoots first. Where two limbs cross and are liable to rub each other, remove one of them, remembering to keep the center of the plant as clear as possible to admit the circulation of air.

The varieties of roses are so numerous that the proper selection is quite difficult. The main divisions of roses are Hybrid Perpetuals, Hybrid Tea, Hardy Climbers, Rugosa and Wichurianas.

BULBS Fall is the time in which to prepare for the feast of flowers so greatly to be enjoyed in the spring. The amateur bulb grower should .place his order early in the fall, say September, so that it may be filled as soon as the bulbs are received from Holland. They may be planted any time from the first of October until the ground is frozen.

The first work in preparing the bed for bulbs is to cover the surface with a good coating of well rotted manure; then spade up the earth deeply. Plunge the spade or fork down to the full depth and turn up the earth from the bottom. After spading, rake down the earth from the center to make the bed perfectly level. It may we well to use a little dibble so as to get all the bulbs planted at the same depth. The only objection to this is that it sometimes compresses the soil too much, leaving a hollow place underneath the bulb. This should be filled with coarse sand before the bulb is set. Close contact with the soil is essential. Standing water at the base of the bulb will cause the

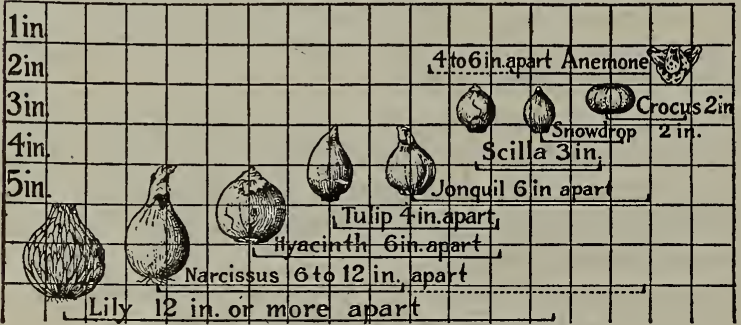

Diagram Showing Depth to Plant Bulbs.
Hyacinths, daffodils and tulips should be

planted five or six inches apart and about four inches deep. The Poet's Narcissus, and some others with comparatively small bulbs, need to be only four inches apart. Snowdrops, crocuses, scillas and other small bulbs may be set two and a half to three inches apart, and about two and a half inches deep.

After the ground has been frozen in the early winter, give the bulb bed a winter protection of leaves or straw manure, or some other light material which can be kept from blowing away by a covering of evergreen boughs. roots to decay. Generally speaking all the Dutch bulbs thrive better for having some sand mixed with the soil. Firm the soil well around the base of the bulb.



Tulip. 
This mulch is to prevent successive freezing and thawing; therefore, do not place it on the beds before they are frozen. The protecting material should be removed in the spring as soon as all danger of frost is past. Beds of bulbs in masses, left over from year to year, should have a coating of manure each fall.

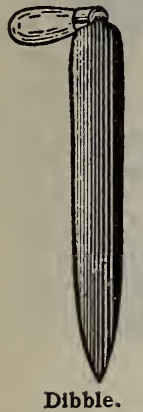

The directions for planting the Hyacinths apply to Tulips. The class called "Bedding Tulips" are, generally speaking, the best to plant in beds. This class does not include any of the late flowering varieties or the "Parrot" Tulips.

After a little experimenting and reading about Tulips, a succession of bloom may be had for at least a month, the joy of which will remain through the year.

\section{DAFFODILS AND NARCISSI}

The Narcissi do well in any soil, except the two extremes

of sand or clay, but good drainage is essential. Prepare the ground thoroughly, for the.bulbs are to remain undisturbed for five or six years, until they get so thick that they crowd the surface. Set the bulbs five or six inches apart and cover about four inches deep.

As soon as the surface of the soil is frozen, cover it from four to six inches deep with strawy manure, and in the early spring rake this off before the shoots come up. When the flowers come, do not let the seeds form, but cut the flower stalks, or the bulbs cannot ripen well, and the flowers next year will be inferior. For the best "cut-flowers" cut them as soon as the bud opens. They will keep much longer.

A beautiful floral picture may be created by naturalizing the Poet's Narcissus.

Snowdrops are the very earliest of all spring flowers, coming into flower very soon after the snow disappears.

For the very earliest yellow flower, use the winter Aconite (Eranthus Hyemalis). It comes into bloom long before the winter is past. The old fashioned crown imperial (Fritillaria Imperalis) known to everybody, but somehow not much planted (possibly because of the disagreeable odor of the flowers), should be planted as early in the fall as the bulbs can be obtained.

The Spanish and English Irises should not be neglected, as they are very beautiful and bloom earlier than the German

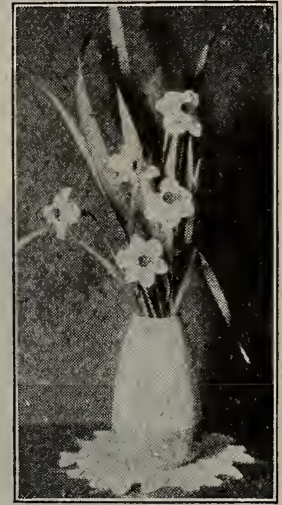

Narcissus.

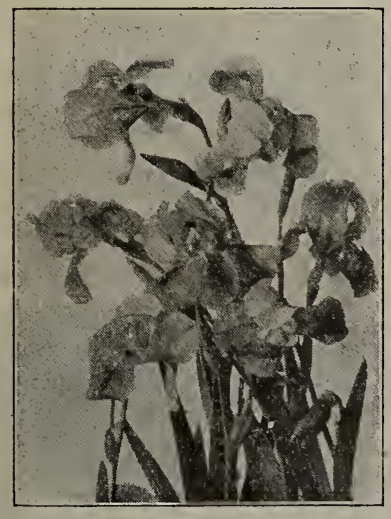

Iris. or Japanese sorts. These both start growing early in the spring, and therefore must be planted in the fall. The Spanish Iris thrives best in moist locations.

The German, Japanese and Siberian Irises follow and should all have a special place in the border. These should be planted in the fall, about four inches deep and should be protected during the winter by a mulch. When it is possible to plant the Japanese and Siberian varieties on the back of a pool or lake, they will flourish most luxuriantly.

In planting the fall bulbs, do not forget the Lilies, for they possess a grace and beauty all their own, There are, at least, fifty varieties of Lilies, perfectly fitted to American gardens. All of these Lilies are easy to grow. Plant them in the fall in ordinary garden soil. By selecting carefully, a succession of bloom may be had for five successive monthsfrom June to October.

Lilies should be planted as soon as the bulbs can be obtained in the fall, as the growth will be stronger and better than from the same bulb planted in the spring.

Whenever and wherever the Lilies are planted, consider the comparative permanence and do not plant where they are subject to disturbance or surface cultivation.

The bulbs should be planted from four to eight inches deep, according to the size of the bulb. It is well to have some good, sharp sand at hand and put some in each hole to form a sand base upon 
which the bulbs can rest. Some growers even envelope the whole bulb in an inch of sand. This is a protection from insects and obviates stagnation of moisture around the bulb.

As a rule, Lilies like a rich soil, but it seems to be the general opinion of all who have experimented in growing them, that the manures (particularly fresh manures) should not be allowed to come into direct contact with the bulbs. Many advocate the application of all manures as a mulch, letting the rains carry down the fertilizing ingredients.

Lilies as a rule do better when set at considerable depth. They seem to resist drought better and the bulbs no doubt keep cool in hot weather.

Most Lilies have two sets of roots, one lot growing at the base of the bulb, the other coming from the stem between the top of the bulb and the surface of the soil. Deep setting is necessary to this root growth

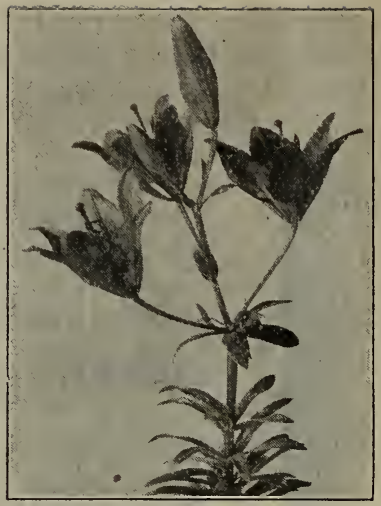

Lilies.

\section{THE SUMMER FLOWERING BULBS Come in a class to themselves,} but furnish a very valuable and attractive lot of plants which are indispensable to the garden.

None of these bulbs should be planted out in the spring until the ground has commenced to warm up and danger of frost has passed. They are of easiest possible culture.

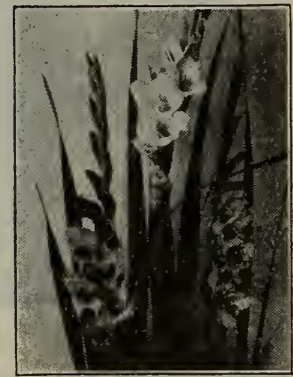

Gladiolus

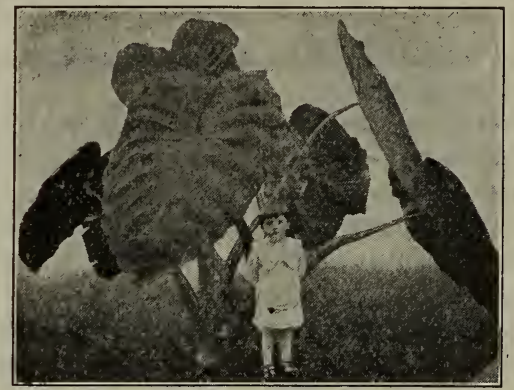

Caladiums.

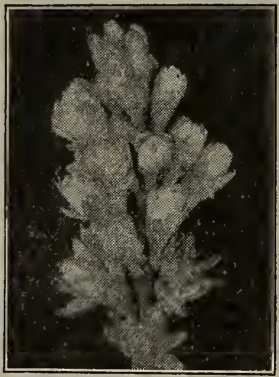

Tuberose

They should have a sunny location, rich, loamy soil, in which case they will be almost sure to bloom.

The most commonly used bulbous plant for summer decoration is the Canna, which produces good effects even when not in bloom.

There is a wide choice in Cannas as they range in height from one and a half feet to six feet. The foliage also varies, being ordinarily green, but there are varieties with deep bronze foliage. The Cannas bear a profusion of bright red and yellow flowers which are very showy.

The glorious Gladiolus is one of the most satisfactory summer flowering bulbs, but if used in the border needs some low growing plant in front of it.

- The bulbs should be planted two inches deep and four or five inches apart, and if used for bedding purposes the rows should be about ten inches apart, so that in two or three weeks another planting may be made between the original rows. This will insure a succession of bloom until almost time for frost.

There is a great diversity of brilliant colors and beautiful markings in the Gladiolus.

One plant which frequently creates some rivalry between near neighbors, who try to see which can grow the largest leaves, is the Caladium (Elephant Ears).

Bulbs of this plant may be put into the ground as soon as danger of frost is past. A moist, rich soil is best. It is impossible to give these too much food. Mulch the soil with four or five inches of well decayed manure and during the dry weather the soil should have frequent soakings.

The Dahlia probably stands next in favor amongst the summer flowering plants. It is better adapted to culture in the back of the garden for cut flowers than as a bedding plant. 
The bulbs of the Dahlia may be set out any time in May. They thrive best in a soil not too rich and with plenty of sunshine. There is a wide range of color and a very great variety in the shape of the Dahlias now, so that they are most interesting and attractive.

The Tuberoses, most fragrant of all flowers, and the Ixias, also deserve mention. All these bulbs need lifting when danger of frost approaches and should be taken in and stored in a cool, dry place until the following spring.

The Paeony is one of the most satisfactory of the herbaceous plants for any garden, because it is long lived and requires but little attention from year to

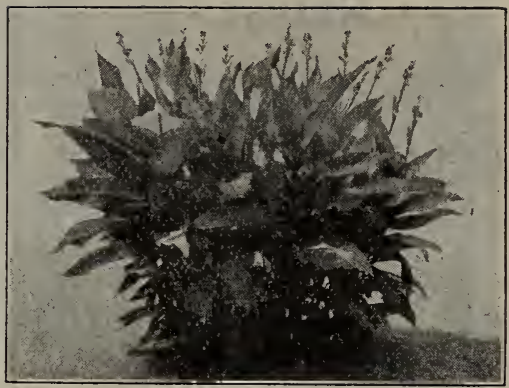

Cannas.

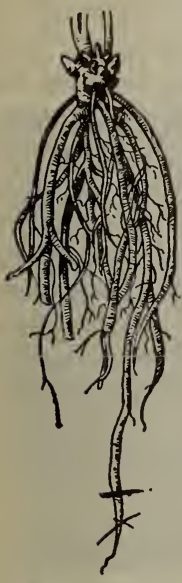

Paeony Root. year. It is seldom troubled by insects or plant diseases and is fine for cut flowers for house decoration.

The best time to plant the Paeony is in the early fall as soon as the growth has ripened-then their roots will have time to make some growth and become established. They may be set in the spring; butit will probably be a year or two before they are established well enough to produce a full crop of flowers.

The Paeony will grow in almost any soil or situation, but for the best flowers the ground must be thoroughly prepared.

Having selected a sunny site for the beds, dig out the soil to a depth of two or three feet, according to the soil. In ordinary loam or heavy clay, two feet is sufficiently deep; in sandy or gravelly loam three feet is better.

In well drained situations, no artifical drainage is necessary, but a sixinch layer of well decayed manure should be thrown in and mixed with the soil taken from the hole, one part manure and three parts soil.

Where the soil is sandy or gravelly, mix some leaf mold, seasoned muck or clayey loam with soil and add the manure to give it a moisture holding capacity.

Set the Paeony roots three feet apart and cover them with three or four inches of soil. In three years these plants will completely shade the ground so no weeds can grow. They should receive a liberal mulch during the winter. As soon as the. ground freezes cut off the stalks to within three inches of the ground. In the spring the strawy part of the mulch should be taken off and the rest worked into the soil, being careful not to injure the crowns and the new growth.

When dividing Paeony bulbs, break them apart, if possible, instead of cutting. Cutting the roots seems to be detrimental.

The Paeony may well be called the "King of Flowers", for it is truly gorgeous, both as to the colorings and the size of the flowers. To the happy possessor of a few choice plants, they act only as an incentive to have more.

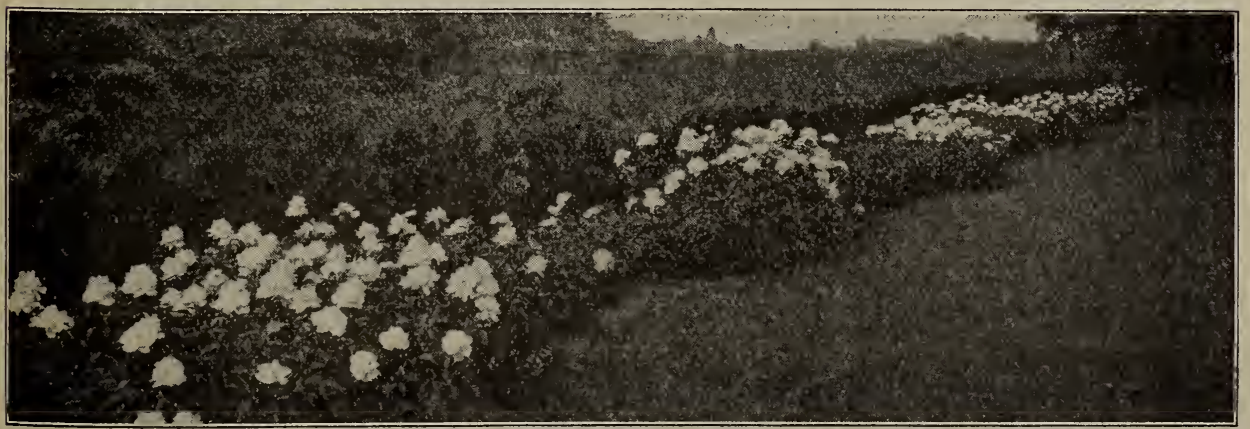

Paeony Bed. 


\section{HEDGES}

There is nothing that will add so much to a place as a hedge if properly placed, cared for and the proper kind of hedge used whether evergreen, deciduous or flowering.

There is no question but what a hedge fence is cheaper than other fences and adds more value to a place when a fence is needed. The pleasure derived from the hedge is worth more than the expense and labor required for its care.

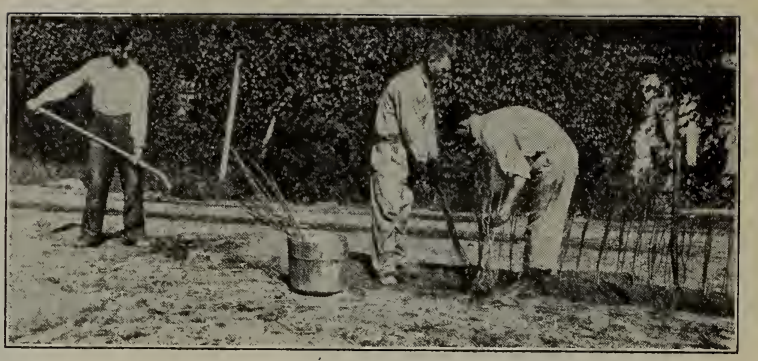

Planting Hedge.

\section{PLANTING A HEDGE}

To get quickest results in planting a hedge, mark out the line where the hedge is to be planted. Dig the ground at least 15 to 18 inches deep and about 2 feet wide along the line made for the hedge. Mix the ground thoroughly with well rotted compost or barnyard manure, pulverize the ground well, and level the top surface, then draw a line exactly where the hedge is to be planted; walk over the line and it will make a mark showing where to plant. If the roots are not to large, the plants may be spaded in as shown in the cut, but if the roots are too large it is best to throw out a ditch large enough to receive the roots without cramping and deep enough so the plants, when properly placed, will be in a few inches deeper than they were planted in the nursery row. When the ground settles it will leave them at about the proper depth. Put the plant at the proper place in the trench or ditch, throw dirt in around the roots, working it up among the roots well, and firm in about two-thirds of the trench with dirt. If the ground is at all dry, put plenty of water in and throw in the remainder of the dirt, but do not firm it for at least a day or two, so as to prevent the dirt hardening around the roots.

'The kind of a hedge to plant depends upon the surroundings, location, and the purpose it is to serve. If it is to serve as a protection against chickens, dogs, cats or stock, it is well to stretch finemeshed 15 to 18 -inch poultry netting on the exact line of the fence.' Plant a row alternately on each side and as near the netting as possible. Within a few months the hedge will grow through this, completely hiding it and making a fence through which even a cat cannot go.

For the ornamental hedge there are many plants that may be used with happy results.

The California Privet leads the list, being better known, therefore more generally used than any other hedge plant. When well kept, a fence of this is very effective. It thrives in almost any soil and seems to be equally happy in either sunshine or shade. It does not usually suffer from drought. Sometimes the winter is too severe for it. Then trim back close to the ground and in a short time the hedge will be as beautiful as before.

The Ibota Privet is not as well known as the California, but is more hardy. It will do well as far north as St. Paul, Minnesota.

There is still another Privet, with two varieties that are very satisfactory. The one, Amoor River Privet North, is very hardy but not as pretty as the Amoor River Privet South, which is evergreen in the South, but not suitable for planting in the North.

To obtain the best and quickest results with the Privets, the plants should be one or two years old and twelve to eighteen or eighteen to twenty-four inches high.

1 The thorn hedge should be planted about eight inches apart in the row. They are of rather slow growth, but owing to the spines makes a hedge which cattle seldom attempt to break through. If kept properly trained from the first, so as to make the bottom full and close, it will even exclude a small dog. 
Chief among these are the Honey Locust of which two-year-old transplanted stock is preferred. The Buckthorn and English Hawthorn also make desirable hedges. Two-year-old plants are commonly used. The Common and Thunbergii Berberry are really the most popular and more ornamental than the foregoing varieties of Thorn Hedges. Two-year-old plants are to be preferred. The sizes generally used of the Common Berberry are eighteen to twenty-four

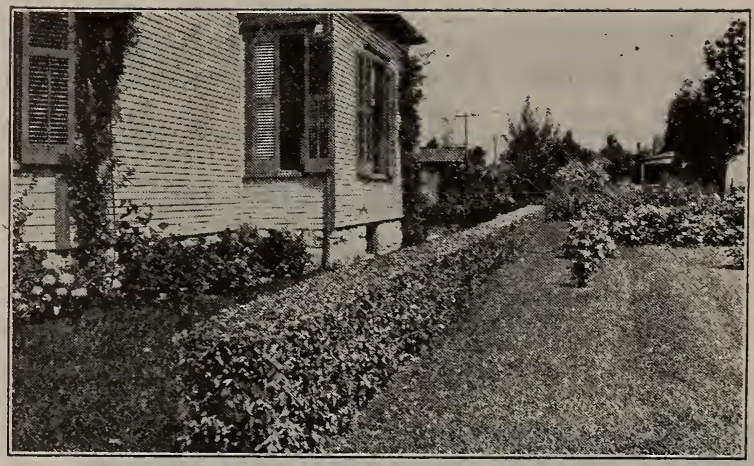

Well Trimmed Hedge. inches and two to three feet. Of the Thunbergii, twelve to eighteen inches and eighteen to twentyfour inches, transplanted stock.

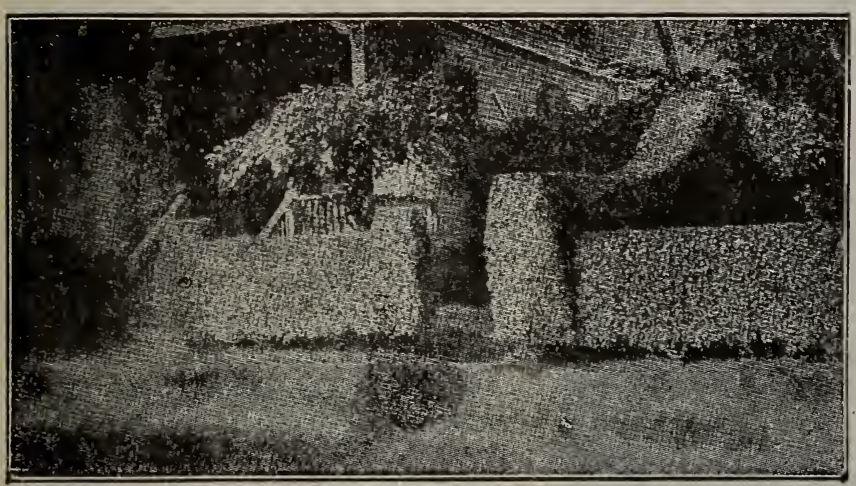

Possibilities in Hedge Trimming.
Among the Flowering Hedge Plants there are a great number that have proven most satisfactory, chief among these being the Althea or Rose of Sharon. This is very effective even early in the season before the blossoms appear. The foliage is light green and handsome. The flowers begin to appear usually the latter part of July and continue until frost.

The Spirea Van Houtii also makes a very attractive hedge. Nothing can excel in beauty the long, drooping, arched branches of this Spirea when covered with its load of white blossoms in May.

The Rosa Rugosa, and Sweet Brier Rose, make a charming hedge and stand exposure well.

The above plants should all be planted about twelve inches apart and two-year-old plants either eighteen to twenty-four inches or two to three feet are preferred.

Climbing Roses are also effective in hedges and should be set two to three feet apart; two-yearold plants are preferred.

Notwithstanding the enthusiasm generally shown for the deciduous hedges, and the delight we get from the hedges of the beautiful flowering shrubs, there is nothing that will quite take the place of an evergreen for the hedge or that furnishes so good a protection against winter's chilling blasts.

The Hemlock Spruce is probably the evergreen which holds first place for hedges and windbreaks. Four-year-old transplanted stock, 18-24 inches high is preferred.

Norway and White Spruce are other valuable evergreens for hedges and windbreaks. Four-yearold transplanted trees are also preferred in these as in all other evergreens for this purpose. The Norway Spruce should be twelve to eighteen inches and the White twelve to eighteen or eighteen to twenty-four inches high. 
The Arbor Vitae is probably equal to the Hemlock Spruce. It is stouter and stiffer and will better endure a small degree of neglect. Little trees twelve to eighteen and eighteen to twenty-four inches high are most to be desired.

\section{TIME FOR TRIMMING HEDGE}

Hedges can be trimmed at any time, with the exception of flowering hedge. These should not be trimmed until after they are through blooming, then trim them so they can form blooming wood for the next season's flowers. As to the shape of the hedge, this depends on your own llkes and dislikes and what is needed to be in harmony with the surroundings.

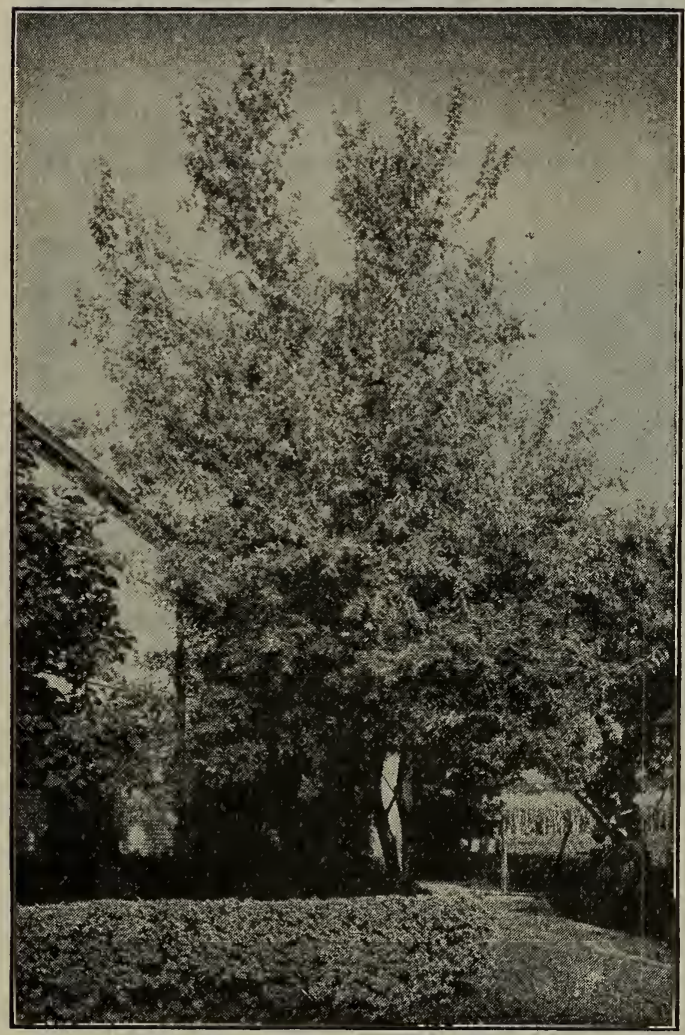

Russian Wild Olive Hedge

Lombardy Poplar, 3-year-old, 4-6 feet and 6-8 feet.

White Spruce, 6-year-old, 2-3 feet. Hornbean, 4-year-old, 2-3 feet.

\section{WINDBREAKS While the} hedge serves, in a measure, as a protection from the piercing winds of winter, yet it is frequently desirable to have a tall hedge or windbreak. Professor Bailey suggests that it is not always necessary to protect ourselves from all sorts of winds. When the wind passes over a large body of water it becomes several degrees warmer than the atmosphere, by taking up the heat from the water as well as the moisture. In this case a windbreak would be detrimental. From a general study of the subject it seems that for interior localities, a dense belt of evergreens with a background of deciduous trees, to keep the evergreens from becoming ragged, is advisable, because winds coming over the land are liable to make the plantation colder. A Windbreak may exert a great infuence over a fruit plantation. The bènefits derived from a windbreak are, protection from cold, lessening amount of evaporation, enabling the trees of an orchard to grow more erect and furnishing homes for birds.

Grape, evergreen honeysuckle or other vines may be so planted as to trail over the branches, thus producing a natural effect besides furnishing a large amount of grapes for home use and for food for the birds.

The following varieties of trees are among the most desirable ones to be used.

\footnotetext{
European Larch,3-year-old, 4-6 feet and 6-8 feet.

Austrian Pine, 4-year-old, 2-3 feet and 3-4 feet.

Norway Spruce, 4-year-old, 2-3 feet.
}

The trees for a windbrake should be planted, wherever possible in a double row from 10 to 12 feet apart.

SPRAYING. Information on when and how to spray may be obtained free by writing the State Experimental Station, State Department of Agriculture, or United States Department of Agriculture, Washington, D. C. 


\section{FRUIT TREES OF OLD TESTED KINDS THAT HAVE \\ PROVEN SATISFACTORY OVER THE GREATEST RANGE OF TERRITORY FOR HOME USE.}

APPLE.

Yellow Transparent, early.

Duchess, early.

Jonathan.

Horse.

Early Harvest.

Red June.

Delicious.

\begin{tabular}{ll}
\hline & CHERRY. \\
Montmorency. & Yellow Spanish. \\
Early Richmond. & Black Tartarian. \\
Dye House. & Gor. Wood.
\end{tabular}

QUINCE.

Orange. Champion.
Grimes Golden.

York Imperial.

Rome Beauty.

Staymans Winesap.

Wine Sap.

Winter Banana.

PEAR.

Kieffer. Clapp's Favorite.

Duchess. Flemish Beauty.

Bartlett. Garber.

Wilder's Early. Dixie.

McLeroy.

PEACH.

$\begin{array}{ll}\begin{array}{l}\text { Elberta. } \\ \text { Champion. }\end{array} & \begin{array}{l}\text { Salway. } \\ \text { Hiley. } \\ \text { Carman. } \\ \text { Mayflower. }\end{array} \\ \end{array}$

\section{PLUM.}

Abundance. $\quad$ Red June.

Lombard. Wickson.

Burbank. Shropshire Damson.

\section{SMALL FRUITS.}

$\begin{array}{ll} & \text { GRAPE. } \\ \text { Concord. } & \text { Brighton. } \\ \text { Worden. } & \text { Delaware. } \\ \text { Niagara. } & \text { Lutie. }\end{array}$

CURRANTS.

Cherry.

Fay's.

Wilder.

White Grape.

Red Cross.

\section{RASPBERRY.}

Cumberland.

Cardinal.

Eureka.
Cuthbert

\section{STRAWBERRY.}

Haverland.

Bubach.

Klondyke.
Senator Dunlap.

Uncle Jim.

St. Louis.

\section{GOOSEBERRY.}

Downing. . Houghton.

\section{BLACKBERRY.}

Eldorado.

Mersereau,

Snyder. 
The following lists are only suggestive. It is not aimed to list all the Trees, Shrubs, etc., but just a few choice ones from each class, one plant frequently appearing in several lists.

\section{ORNAMENTAL TREES ASSEMBLED FOR SPECIAL PLACES.}

\section{TREES FOR CITY PLANTING.}

Ash, American; Fraxinus Americana. Elm, American; Ulmus Americana.

Linden, American; Tilia Americana.

Linden, European; Tilia Europea.

Sycamore, American; Platinus Occidentalis.

Oak White; Quercus Alba.

Oak Scarlet; Quercus Coccinea.

Maple Norway; Acer Platinoides.

Maiden Hair Tree; Ginkgo Biloba.

Tree of Heaven; Ailanthus Glandulosa.

Soft Maple; Acer Saccharinum.

\section{TREES FOR WINTER BEAUTY.}

Sycamore; Platinus Occidentalis.

White Birch; Betula Alba.

Beach; Fagus Sylvatica.

Willow Golden Bark; Salix Vitellina.

Ash Golden Bark; Fraxinus Excelsior Aurea.

\section{WEEPING TREES.}

Cut Leaf Weeping Birch; Betula Alba Var. Pendula Laciniata.

Elm Camperdown; Ulmus Scabra. var. Pendula. Maple Weir's Cut Leaf; Acer Saccharinum var. Weir's Lacinata.

Mulberry; Tea's Weeping; Morus Alba var. Tartarica Pendula.

Willow Kilmarnock Weeping; Salix Caprea varPendula.

\section{MOST POPULAR TREES.}

Maple, Norway; Acer Platinoides. Linden, American; Tilia Americana.

Birch, White; Betula Alba.

Sycamore; Platinus Occidentalis.

Willow, Yellow Bark; Salix Vitellia.

Sumac, Staghorn; Rhus Typhena.

Sof t Maple; Acer Saccharinum.

American Elm; Ulmus Americana.

White Ash; Fraxinus Americana.

Oak; Quercus.

\section{TREES WITH ATTRACTIVE AUTUMN FOLIAGE.}

Maple Sugar; Acer Saccharum.

Oak, White; Quercus Alba.
Oak Scarlet; Quercus Coccinea.

Sweet Gum; Liquidamber Styraciflua.

Tulip Tree; Liriodendron Tulipifera.

\section{LEADING EVERGREENS.}

Arborvitae, American; Thuya Occidentalis.

Arborvitae, Pyramidalis; Thuya Occidentalis var. Pyramidalis.

Arborvitae, Siberian; Thuya Siberica.

Arborvitae Globosa; Thuya Globosa.

Arborvitae Compacta; Thuya Compacta.

Arborvitae, Peabody's Golden; Thuya Occidentalis Lutea.

Cedar, Red; Juniperus Virginiana.

Cedar, Red; Juniperus Virginiana var. Glauca.

Cedar, Red; Juniperus Sabina.

Fir, Balsam; Abies Balsamea.

Hemlock Spruce; Tsuga Canadensis.

Juniper, Irish; Juniperus var. Hibernica.

Pine, Austrian; Pinus Austrica.

Pine, Scotch; Pinus Sylvestris.

Pine, Yellow; Pinus Ponderosa.

Pine, White; Pinus Strobus.

Pine, Dwarf; Pinus Mughus.

Retinispora Plumosa Aurea.

Retinispora Pisifera Aurea.

Retinispora Squarrosa Veitchii.

Retinispora in many other varieties.

Spruce, Norway; Picea Excelsa.

Spruce, White; Picea Alba.

Spruce, Koster's Blue; Picea Excelsa. var. Kosteriana.

Spruce, Colorado Blue; Picea Pungens.

Spruce, Alcockiana; Picea Alcockiana.

Spruce, Glauca; Picea Pungens var. Glauca.

\section{BROAD LEAVED EVERGREENS.}

Rhododendrons.

Mahonia, Holly Leaved; Mahonia Aquifolia.

Boxwood Pyramids, Globes and Standards.

Boxwood Edging.

Kalmia Latifolia.

Euonymous Radicans.

Euonymous Radicans var. Variegated.

\section{TREES FOR FORMAL EFFECT.}

Cork Bark Maple; Acer Campestre.

Camperdown Elm; Ulmus Camperdownii.

Catalpa Bungii.

Weeping Mulberry; Morus Alba var. Tartarica Pendula. 


\section{MOST POPULAR SHRUBS.}

Berberry, Japanese; Berberis Thunbergii.

Deutzia Gracilis.

Hydrangea Paniculata Grandiflora.

Snowball; Viburnum Sterilis.

Spirea Van Houtii.

Syringa; Philadelphus, in Varieties.

Weigelia Diervilla Rosea.

Lilac; Syringa Vulgaris.

Rose of Sharon; Alshea.

Currant, Golden; Ribes Aureum.

Bush, Honeysuckle; Lonicera Tartarica.

Deutzia Lemoinei.

Deutzia, Pride of Rochester.

High Brush Cranberry; Vibrunum Opulus.

Spirea Anthony Waterer.

Hydrangea Arborescens.

Purple Berberry; Berberis Purpurea.

Common Berberry; Berberis Vulgaris.

Snowball, Japan; Viburnum Tomentosa.

Snowberry; Symphoricarpus Racemosus.

Coral Berry; Symphoricarpus Vulgaris.

Red Twig Dogwood; Cornus Mascula.

\section{SHRUBS WITH SMALL BUT NUMEROUS FLOWERS.}

Buckeye Dwarf; Aesculus Parviflora.

Button Bush; Scphalanthus Occidentalis.

White Fringe; Chionanthus Virginica.

Golden Currant; Ribes Aureum.

Judas Tree; Cercis Canadensis.

Smoke Tree; Rhus Cotinus.

Spice Bush; Lindera Benzoin.

Thorn; Crataegus Oxycantha.

Spirea Van Houtii.

Spirea Anthony Waterer.

\section{SHRUBS THAT BLOOM FOR EIGHT WEEKS OR MORE.}

Kerria Japonica, var. flora plena.

Pepperbush, Sweet; Clethra Alnifolia.

Hills of Snow; Hydrangea Arborescens.

St. John's Wort; Hypericum Prolificum.

Hydrangea Paniculata Grandiflora.

Weigelia Eva Rathke; Diervilla Hybrida Eva Rathke.

Rosa Rugosa.

Rhodotyphus Kerroides.

Spirea Billardia; Spirea.

Spirea Billardia Alba.

Spirea Douglasii.

Buddleia Lindleyana.

\section{SHRUBS FOR CUT FLOWERS.}

Lilacs, Syringa in varieties.

Spirea, in varieties.

Deutzia, Pride of Rochester.

Hydrangea, Paniculata Grandiflora.

Mock Orange; Philadelphus Coronarius.

Snowball; Viburnum Opulus var. Sterilis.

Tick Trefoil; Desmodium Penduliflorum.

Weigelia in varieties.

\section{SHRUBS ATTRACTIVE IN FRUIT.}

Berberry, Japanese; Berberis Thunbergii. Rosa Rugosa.
Snowberry; Smyphoricarpus Racemosus.

Coral Berry; Symphoricarpus Vulgairis.

Strawberry Tree; Euonymus Americana.

Rhodotyphus Kerrioides.

High Bush Cranberry; Viburnum Opulus.

\section{SHRUBS WITH VARIOUSLY COLORED LEAVES.}

Plum, purple leaved; Prunus Pissardi.

Filbert, purple leaved; Corylus Maxima var. Purpurea.

Syringa, Golden Leaf; Philadelphus Aurea.

Elder, Golden Leaf; Sambucus Nigra var. Aurea.

Berberry, Purple Leaved; Berberis Vugaris var. Atropurpurea.

Weigelia var. Leaved; Diervilla Florida var. Nana Variegata.

Althea var. Leaved.

Snowberry var. Leaved; Symphoricarpus Racemosus var. Variegata.

\section{SHRUBS WITH COLORED BARKS.}

Dogwood Siberica; Cornus Siberica.

Dogwood, Red Osier; Cornus Stolnifera.

Kerria, Japonica.

Strawberry Bush; Euonymus Americana.

\section{SHRUBS THAT RESIST DROUGHT.}

Cherry, Sand; Pumila Bessyi.

St. John's Wort; Hypericum Kalmianum.

Tamarix, Chinensis.

Russian Olive; Eleagnus Angustifolia.

Eleagnus Longipes.

Siberean Pea Tree; Caragana Arborescens

\section{SHRUBS FOR COLD CLIMATES.}

Button Bush; Cephalanthus Occidentalis Golden Currant; Ribes Aưrea.

Sumac Cut Leaf; Rhus Lacinata.

June Berry; Amelanehier Botryapium.

Sheepberry; Viburnum Lentago.

Lilac Persian; Syringa Persica.

Bush Honeysuckle; Lonicera Tartarica.

Lilac; Syringa Vulgaris.

Coral Berry; Symphoricarpus Racemosus.

Syringa; Philadelphus Coronarius.

Snowball; Viburnum in varieties.

\section{SHRUBS FOR SUNNY PLACES.}

A'spice, Carolina; Calycanthus Floridus. Bastard Indigo; Amorpha Fruticosa.

Oleaster; Eleagnus Arguta.

Blue Spirea; Caryopteris Masticanthus.

\section{SHRUBS FOR SHADY PLACES.}

Andromeda Floribunda.

Mahonia Berberis Aquifolium.

St. John's Wort; Hypericum Aureum.

Snowberry; Symphoricarpus Vulgaris

Hazelnut; Corylus Americana.

Red Bud; Cercis Canadensis.

Dogwoods in variety; Cornus. 


\section{SHRUBS FOR SCREENS.}

Bush Honeysuckle; Lonicera Tartarica. Syringia; Philadelphus in Varieties.

Lilacs, Syringa in Varieties.

Snowball; Viburnum Opulus var. Sterilis.

Russia Olive; Eleagnus Angustifolia.

Deutzia Crenata.

Purple Fringe; Rhus Cotinus.

White Fringe; Chionanthus Virginica.

Tamarix, in Variety.

Hercules Club; Aralia Spinosa.

Cut Leaf Elder; Sambucus Canadensis var. Lanceolate.

\section{SHRUBS THAT BLOOM IN APRIL.}

Goldenbell; Forsythia Suspensa.

Shad Bush; Amelanchier Canadensis.

Spirea Thunbergii;

Quince, Japan; Cydonia Japonica.

\section{SHRUBS THAT BLOOM IN MAY.}

Almond Flowering; Prunus Amygdalus.

Spirea.

Bush, Honeysuckle; Lonicera Tartarica.

Berberry, Common; Berberis Vulgaris.

Lilac, Persian; Syringa Persica.

Rhodotyphus Kerroides.

Snowball, Common; Viburnum Opulus var. Sterilis.

Silverbell; Helesia Tetraptera.

Weigelia Rosea; Diervilla Rosea.

Syringa; Philadelphus Coronaria.

Azalea Mollis.

Red Bud; Cercis Canadensis.

Dogwoods; Cornus.

SHRUBS THAT BLOOM IN JUNE.

Bastard, Indigo; Amorpha Fruticosa var. Fragrans.

Deutzia, Gracilis.

Kerria, Japonica.

\section{SHRUBS THAT BLOOM IN JULY.}

Botton Bush; Cephalanthus Occidentalis.

Pepperbush; Clethra Alnifolia.

Spirea Douglasii.

Spirea Anthony Waterer.

Hills of Snow; Hydrangea Arborescens.

SHRUBS THAT BLOOM IN AUGUST.

Tick Trefoil; Desmodium Penduliflorum.

Sumac; Rhus Coronaria.

Hydrangea Paniculata Grandiflora.

Snowberry; Symphoricarpus Racemosus.

\section{SHRUBS THAT BLOOM IN SEPTEMBER OR LATER.}

Spirea, Blue; Caryopteris Masticanthus.

Spirea Callosa Alba.

Witch Hazel; Hamamelis Virginica.

Weigelia Eva Rathke; Diervilla Hybrida var. Eva Rathke.

Spirea, Billardia.

Spirea, Anthony Waterer.

\section{SHRUBS WITH WHITE FLOWERS.}

Deutzia Gracilis.

Pepperbush; Clethra Alnifolia.

Syringa; Philadelphus Grandiflora.

Silverbell; Helesia Tertaptera.

Dogwood, Siberian; Cornus Siberica.
Sweet Syringa; Philadelphus Coronarius.

Snowball; Viburnum in varieties.

Lilac; Syringa Alba.

Althea.

Honeysuckle, Upright; Lonicera Alba.

Spirea Van Houtii.

Spirea Callosa Alba.

Hills of Snow; Hydrangea Arborescens.

\section{SHRUBS WITH YELLOW FLOWERS.}

Golden Bell; Forsythia Suspensa.

Currant, Golden; Ribes Aureum.

St. John's Wort; Hypericum Aureum.

Berberry, Common; Berberis Vulgaris.

Kerria Japonica.

\section{SHRUBS WITH RED FLOWERS.}

Althea.

Red Bud; Cercis Canadensis.

Currant Red Flower; Ribes Sanguineum.

Honeysuckle Bush; Lonicera. Tartarica.

Weigelia Eva Rathke; Diervilla Hybrida var. Eva Rathke.

Spirea Douglasii.

Spirea Billardia Rosea.

Spirea Anthony Waterer.

Tamarix.

Lilac, Charles X.

\section{SHRUBS LESS THAN TWO FEET HIGH.}

Yellow Root; Xanthoceras Sorbifolia.

Deutzia Gracilis.

Spirea Anthony Waterer.

Spirea Callosa Alba.

\section{SHRUBS BETWEEN TWO AND THREE FEET}

Berberry, Holly Leaved; Mahonia Aquifolia.

Spirea Thunbergii.

Berberry, Japanese; Berberis Thunbergii.

St. John's Wort; Hypericum Prolificum.

\section{SHRUBS THREE TO FOUR FEET.}

Buckthorn, Sea; Rhamnus Cathartica.

Kerria Japonica.

Euonymus Radicans.

Deutzia Lemoine.

Tick Trefoil; Desmodium Dillenii.

\section{SHRUBS FIVE TO EIGHT FEET.}

Cut Leaf Sumac; Rhus Glabra var. Lacinata.

Berberry, Common; Berberis Vulgaris.

Cut Leaf Elder; Sambucus Nigra var. Lacinata.

Golden Bell; Forsythia Suspensa.

Golden Elder; Sambucus Nigra var. Aurea.

Japanese Rose; Kerria Japonica.

Spirea Billardia.

Rose Acacia; Robinia Hispida.

Snowball, Japan; Viburnum Tomentosa.

Deutzias in variety.

High Bush Cranberry; Viburnum Opulus.

Hydrangea P. G. Tree Form.

Snowball, Common; Viburnum Opulus var Sterilis.

Hills of Snow; Hydrangea Arborescens.

Spirea Van Houtii.

Sweet Syringa; Philadelphus Coronaria.

Syringa Golden Leaf; Philadelphus Aurea. 
SHRUBS MORE THAN EIGHT FEET.

Hercules Club; Aralia Spinosa.

Silverbell; Halesia Tetraptera.

Wayfaring Tree; Viburnum Lantana.

Sumac; Rhus Coronaria.

Purple Fringe; Rhus Cotinus.

Russian Olive; Eleagnus Angustifolia.
Rose of Sharon; Althea.

Tamarix, in varieties.

White Fringe; Chinensis Virginica.

Perennial Flax; Linum Perenne.

Shrubs may be trimmed at any time and formed into any desired shape, but the best time for trimming is usually just after blooming season.

\section{PERENNIALS ASSEMBLED FOR SPECIAL PLACES.}

\section{MOST POPULAR PERENNIALS.}

Columbine; Aquilegia in varieties.

Anemone; Japonica.

Coneflower; Rudbeckia Purpurea.

Hollyhocks; Althea Rosea.

Iris, German; Iris Germanica.

Iris, Japanese; Iris Kaempferia.

Peonies in variety.

$\mathrm{Phlox}$ in varieties.

Sunflower; Helianthus in varieties.

Larkspur; Delphinium in varieties.

Sweet William; Dianthus Barbatus.

May Pinks; Dianthus in varieties.

Fox Glove; Digitalis Gloxiniaeflora.

Golden Glow; Rudbeckia Lanceolate.

Coreopsis Lanceolate.

Gaillardia Grandiflora; Blanket Flower.

\section{PERENNIALS FOR CUT FLOWERS.}

Columbina; Aquilegia in varieties.

Coreopsis Lanceolate.

Daisy Shasta, and Alaska.

Giallardia Grandiflora.

Larkspur; Delphinum Formosum

Chinese Bellflower; Platycodon Grandiflora.

Forget-Me-Not; Myosotis Palustris.

Sneezeweed; Achillia the Pearl.

Hermocallis Flava.

Phlox.

May Pinks; Dianthus in varieties.

Foxglove; Digitalis Gloxiniaeflora.

Perennial Pea; Lathyrus Latifolius.

Iris in varieties.

\section{PERENNIALS THAT BLOOM MORE THAN EIGHT WEEKS.}

Perennial Pea; Lathyrus Latifolius.

Gaillardia Grandiflora.

Coreopsis Lanceolata.

Larkspur; Delphinium.

Speedwell; Veronica Longifolia Subsessitis.

\section{PERENNIALS TO REMAIN UNDISTURBED FOR YEARS.}

Gas Plant; Dictamus Alba.

Iris.

Phlox.

Perennial Pea; Lathyrus Latifolius.

Peony.

May Pink; Dianthus.

PERENNIALS FOR SUNNY PLACES.

Coneflower; Rudbeckia Purpurea.

Sweet William; Dianthus Barbatus.

Beard's Tongue; Penstemon Barbatus.

Baby's Breath; Gypow whi'.ia Paniculata.

Foxglove; Digitalis Gi : xineaflora

Phlox
Gaillardia Grandiflora.

Coreopsis Lanceolata.

Perennial Flax; Linum Perenne.

Shasta Daisy.

\section{PERENNIALS FOR SHADY PLACES.}

Anemone Japonica.

Columbine; Aquilegia in varieties.

Hardy Pansies; Viola Coruna.

Forget-MeNot; Myosotis Palustris.

\section{DROUGHT-RESISTING PERENNIALS.}

Baby's Breath; Gypsophillia Paniculata.

Coneflower; Rudbeckia Purpurea.

Stonecop; Sedum.

Sunflower Hardy; Helianthus in varieties.

\section{WHITE FLOWERING PERENNIALS.}

Achillia Ptarmica.

Day Lily; Funkia'Subcordata Grandiflora.

Snow in Summer; Cerestium Tomentosum.

Shasta Daisy.

Hibiscus Crimson Eye; Hibiscus Moschentos.

YELLOW-FLOWERED PERENNIALS.

Columbine; Aquilegia Chrysantha.

Gaillardia Grandiflora.

Coreopsis Lanceolata.

Hermocallis Flava.

Gold Flower; Hypericum Mosirianum.

Golden Glow; Rudbeckia Lanceolate.

Hardy Sunflower; Helianthus.

\section{PINK-FLOWERED PERENNIALS.}

Hollyhocks; Althea Rosea.

Hardy Hibiscus; Hibiscus Moschentos.

Moss Pink; Phlox Sublata.

Peony.

Garden Pinks; Dianthus.

Phlox; Peach Blow.

RED-FLOWERED PERENNIALS.

Anemone Japonica.

Balm, Fragrant; Monardia Didyma.

Cardinal Flower; Lobelia Cardinalis.

Peony Officinalus Rubra.

Beard's Tongue; Penstemon Barbatus.

\section{BLUE-FLOWERED PERENNIALS.}

Chinese Bellflower; Platycodon Grandiflora. Larkspur; Delphinium Formosum.

Kansas Gay Feather; Liatrus Pycnostachya. Hardy Sage; Salvia Azurea.

Forget-Me-Not; Myosotis Palustris.

Columbine; Aquilegia Coerulea:

Speedwell; Veronica Subsessilis.

Perennial Flax; Linum Perenne.

\section{APRIL BLOOMING PERENNIALS.}

Anemone.

Bloodroot; Sanguinaria Canadensis. 
Candytuft; Iberis Sempervirens.

English Daisy; Bellas Perensis.

MAY BLOOMING PERENNIALS.

Forget-Me-Not; Myosotis Palustris.

Moss Pink; Phlox Sublata.

Lily of the Valley; Convallaria Majalis.

Sweet William; Dianthus Barbatus.

Peony.

Garden Pinks; Dianthus in varieties.

JUNE BLOOMING PERENNIALS.

Sneeze Weed; Achillia Ptarmica.

Bleeding Heart; Dicentra Spectabilis.

Columbine; Aquilegia in varieties.

Beard's Tongue; Penstemon Barbatus.

Baby's Breath; Gypsophillia Paniculata.

Japan Iris; Iris Kaempferii.

Adam's Needle; Yucca Filamentosa.

Blackberry Lily; Pardanthus Chinensis.

JULY BLOOMING PERENNIALS.

Evening Primrose; Oenothera Glauca var. Fraseri.

Canterberry Bell; Campanula Medium.

Perennial Flax; Linum Perenne.

Gaillardia Grandiflora.

\section{AUGUST BLOOMING PERENNIALS.}

Kansas Gay Feather; Liatris Pycnostachya.

St. John's Wort; Hypericum Moserium.

Chinese Bellflower; Platycodon Grandiflora.

Hardy Hibiscus; Hibuscus Moschentos.

Hardy Sage; Salvia Azurea.

Black Eyed Susan; Rudbeckia Newmanii.

SEPTEMBER BLOOMING PERENNIALS.

Cardinal Flower; Lobelia Cardinalis.

Perennial Pea; Lathyrus Latifolia.

Gaillardia Grandiflora.

Coreopsis Lanceolate.

Shasta Daisy.

PERENNIALS BLOOMING AFTER FROST.

Chrysanthemums.

Gaillardia Grandiflora.

Coreopsis Lanceolate.

Perennial Pea; Lathyrus Latifolius.

Snap Dragon; Antirrhinum Majus.

\section{PERENNIALS FOR MOIST GROUND.}

Fragrant Balm; Monardia Didyma.

Cardinal Flower; Lobelia Cardinalis.

Iris, Japanese; Iris Kaempferri.

Joe Pye-Weed; Eupatorium Purpureum.

PERENNIALS WITH STRIKING FOLIAGE.

Giant Reed; Arunda Donax.

Anemone Japinica.

Adam's Needle; Yucca Filamentosa.

Eulalia Zebrina.

\section{- PERENNIALS LESS THAN A FOOT HIGH.}

Grass Wort; Cerastium Tomentosum.

Creeping Phlox; Phlox Sublata.

Forget-Me-Not; Myosotis Palustris.

Hardy Pansy; Viola Coruna.

Candytuft; Iberis Sempervirens.

Garden Pinks; Dianthus.

PERENNIALS ONE TO TWO FEET HIGH.

Sneeze-Weed; Achilla Ptarmica.

Sneeze-Weed; Achillia, The Pearl.

Fragrant Balm; Monardia Didyma.
Columbine; Aquilegia Canadensis.

Bleeding Heart; Dicentra Spectabilis.

Canterberry Bell; Campanula Medium.

Blackberry Lily; Pardanthus Chinensis.

Peony.

Phlox.

PERENNIALS THREE TO FOUR FEET.

Larkspur; Delphinium Formosum.

Tree Peony; Peony Montan.

Chinese Bellflower; Platycodon Grandiflora.

Iris Siberica Purpurea.

Fox Glove; Digitalis Gloxiniflora.

\section{PEREN NIALS FOUR TO SIX FEET.}

Kansas Gay Feather; Liatris Pycnostachya.

Hollyhocks; Althea Rosea.

Coneflower; Rudbeckia Purpurea.

Hardy Sage; Salvia Azurea.

Tick Trefoil: Desmodium Penduliflorum.

\section{ORNAMENTAL GRASSES.}

Giant Reed; Arunda Donax.

False Pampas Grass; Erianthus Ravenna.

Eulalia Japonica.

Eulalia Japonica var. Gacilium.

Eulalia Japonica var. Variegated.

Eulalia Japonica var. Zebrina.

PLANTS FOR GROUND COVERING.

Myrtle; Vinca Minor.

Snow in Summer; Cerestium Tomentosum.

Moss Pink; Phlox Sublata.

Rosea Wichuriana.

\section{VINES FOR ALL PURPOSES.}

Boston Ivy; Ampelopsis Veitchii.

Virginia Creeper; Ampelopsis Quinquefolia. Akabia Quinata.

Trumpet Flower; Bignonia Capreolata.

False Bitter Sweet; Celestrus Scandens.

Maderia Vine.

Kudzu Vine.

Hall's Japan Honeysuckle; Lonicera Halliana.

Matrimony Vine; Lycium Chinensis.

Wistaria Chinensis.

Clematis Paniculata.

Clematis Jackmanii.

Clematis Mad Ed. Andre.

Clematis Henryii.

\section{BULBS.}

\section{POPULAR HARDY BULBS FOR FALL PLANTING.}

Daffodils; Narcissus.

Hyacinths; Hyacinthus.

Jonquills; Narcissus Jonquilla.

Lily; Lillium,

Narcissus Poet; Narcissus Poeticus,

Tulip; Tulipa.

Crown Imperial; Fritillaria Imperialis.

\section{BULBS FOR SPRING PLANTING.}

Gladiolus.

Cannas.

Caladium.

Dahlias.

Bigonia Tuberous Rooted.

Lily of the Valley; Convallaria Majalis.

Tuberoses. 


\section{GOOSEBERRIES}

The gooseberry is gaining in popularity every year. They are excellent for canning and table use while in season.

\section{Downing}

Fruit large, whitish green. Soft, juicy and very.good. Bush upright, vigorous and productive.

\section{Houghton}

Small, pale red, tender, juicy and sweet. An enormous bearer.

\section{CURRANTS}

Currants ripen just before the raspberries are gone and continue for several weeks. They produce a heavy yield of fruit and are very hardy. Useful for jams and jellies.

\section{Cherry}

One of the largest of red currants. Bunches short and compact and borne in great profusión.

Fay's

Of large size, fine flavor and very prolific.

\section{White Grape}

Very large, yellowish white, sweet. Excellent quality and valuable for table. Very productive.

\section{Red Cross}

A new red currant of large size and superior quality. Exceedingly vigorous and productive, with long fruit stems.

\section{CHESTNUT}

Japan

The Japan Chestnut grows well in nearly all parts of the south, and makes handsome spreading dense headed trees. The nuts are esteemed by most people and very good.

\section{ALMOND}

Non Pareil

A sturdy growing, spreading tree that blooms early. Shell very thin. Kernel sweet. 


\section{PECANS}

The demand fur Pecans is steadily increasing-owing to the popularity of nuts as food. The culture is rapidly increasing throughout the south, there being but few trees that will yield as large an amount and as regular after they reach the bearing age. The trees make a beautitul shade and grow fairly rapidly.

\section{Stuart}

Large, averaging forty or fifty to the pound. Shell moderately thin. Kernel bright, plump, flavor rich and good. Tree strong, upright, spreading grower and an abundant bearer.

\section{Van Deman}

Large to very large, rather slender. Shell of medium thickness, crackıng quality excellent. Kernel tull and plump. Flavor sweet and good. Tree is vigorcus, healthy, with large bright foliage.

\section{Pabst} good.

Large, oblong, shell of medium thickness. Kernel large. Flavor and quality

\section{HEDGÉ PLANTS}

Nothing adds to the beauty of home surroundings as a good lawn and well placed shrubs. The smallest lot has a place for a few. Aside from their value in beautifying the grounds they increase the money value of property.

\section{Barberry Japanese}

A low bush, making a dense, thick hedge with small yellow flowers in the spring. Branches covered with small sharp thorns.

\section{Privet, Amoor River}

A densely branched variety of rapid growth with small evergreen leaves. May be pruned in any desired form. Very ornamental.

\section{Privet California}

Excellent for hedges. Half evergreen, holding its beautiful foliage until late in the winter. Very popular.

\section{Spirae Van Houtteii}

The very best flowering shrub in cultivation. The plant is rather tall, upright grower with long, slender branches that droop gracetully. Flowers pure white in great clusters. Very hardy. 


\section{PEACHES}

One of the most profitable and pleasant of the fruits to grow is the peach. The ease with which the trees may be cultivated, comparative freedom from disease and short period before they become productive make peach growing extremely profitable. We offer the following list of the best varieties, ripening from early to late.

\section{EARLY PEACHES}

\section{Mayflower}

The earliest peach. Medium size, slightly oblong. When fully ripe a beautiful red all over. Tree hardy and healthy. Fine seller.

\section{Early Wheeler}

A very early peach and very profitable. Large, round, creamy white and nearly covered with red. Tree is a vigorous grower. Bears third to fourth year.

\section{Red Bird}

The Red Bird is a remarkable peach. Fruit brilliantly colored. The flesh is firm, juicy and good quality. A profitable commercial shipping peach. Ripens about three days after Mayflower.

\section{Greensboro}

Extra large for an early peach. Flesh white, exceedingly tendes and juicy, It has proven its value for commercial growers. Ripens a little later than Mayfower.

\section{Triumph}

The earliest jellow peach, nearly covered with dark red. Desirable for home *orchard. . Flesh juicy and rich.

\section{Carman}

\section{SUMMER PEACHES}

The Carman is the standard market peach of its season. Large, creamy white with red tinge. Good shipper. A favorite variety with large growers.

\section{Waddell}

- Fruit medium to large, creamy white, flesh firm and sweet. Free stone and resistant to rot.

\section{Arp Beauty}

A làrge beautiful peach with mottled red cheek. Flesh is yellow and quality very good. A good shipping peach and very valuable. 


\section{Hiley (Early Belle)}

Rich creamy white with fine flesh. One of the best shippers and invariably brings top prices.

\section{Chinese Cling}

Large, transparent, cream color. Very juicy and melting. One of the most popular.

\section{Champion}

A western peach of very large size, and regular bearer, creamy white. Flesh sweet and delicious.

\section{Belle of Georgia}

A roundish, white peach with red cheek, firm flesh. Very prolific bearer and dependable. Specially recommended for commercial planting and home use.

\section{Elberta}

\section{SEPTEMBER PEACHES}

The great market peach, large golden yellow with red cheek. Flesh yellow, juicy and sweet and rich. Tree very prolific and hardy.

\section{Matthews' Beauty}

Extra large, yellow, with red cheek. A good market peach. Free stone.

\section{Emma}

A very large, yellow peach. Fine grained, very juicy. Free stone of good quality.

\section{Mamie Ross}

Creamy white, almost covered with a carmine blush. Strong, vigorous growing tree. Can always be depended upon to bear large crops.

\section{Old Mixon Free}

Fine, large, productive variety, in high favor as an orchard variety. Yellowish white with deep red cheek.

\section{Crawford's Late}

Large and beautiful. Fine quality, very popular old variety for canning and always brings good prices on the market. Free stone.

\section{Salway}

A late peach. Large, yellow, with a brownish red cheek. Flesh deep yellow, red at pit, very sweet, juicy and good. The Salway can be picked when green and it will ripen in storage or on the way to market. 


\section{WINTER APPLES}

Gano

A handsome, large red apple, smooth and brilliant. Flesh is white. Tree is very healthy, vigorous and hardy, producing regular and abundant crops.

\section{Jonathan}

Brilliant dark red apple of excellent quality. Flesh tender, spicy, rich and its flavor is full of snap and sparkle which makes it one of the best quality and most profitable apples of its season. Will keep well and stand much handling.

\section{Kinnard's Choice}

Large size, dark red on yellow ground, showy apple. Bears quite young. Quality one of the best.

\section{Mammoth Black Twig}

Extra large and round, smooth, yellowish, covered with deep red. Flesh tender, crisp, sub-acid. Excellent quality and a most dependable variety.

\section{Ben Davis}

Finest keeper. Good looking large yellow apple, with red stripes. Flesh white, juicy and coarse. Tree rapid in growth and bears abundantly.

\section{Baldwin}

Northern winter apple. Medium bright red. Flesh yellow and rich. Popular and profitable.

\section{McIntosh Red}

Medium to large, purplish red. The crisp, snow white flesh is very tender and juicy. 'The tree is long lived, bears fourth to fifth year. Thrives best in the northwest.

\section{Paragon}

Large, fine grain with mild pleasant flavor. A strong grower and abundant bearer. An excellent keeper and comes into bearing early.

\section{Delicious}

Considered to be the finest winter apple. It is distinctive in shape, large and very beautiful, being almost covered with dark red. Flesh is fine, firm and tender, highly flavored. In keeping quality it ranks with the best and does not bruise readily.

\section{Stayman's Winesap}

Medium to large, yellow and red. Fine grained, sub-acid. Quality the best. Trees very productive.

\section{York Imperial}

Large, blocky apple, a greenish yellow with bright red stripes. Flesh tender, brittle, but juicy and good quality. Tree strong and healthy and an unusually heavy bearer. 


\section{APPLES}

Apples are the one all-purpose fruit for every locality. Every one should have some apple trees, and in selecting kinds tor the home orchard there should be a few early bearing sorts, also some fall varieties and a liberal number of late sorts to keep during the winter. Apple trees will thrive almost anywhere, and are very profitable when grown for commercial purposes.

\section{Early Harvest}

Very early apple of medium size, pale yellow, juicy, crisp, and well flavored. Fine for cooking and an old favorite.

\section{Yellow Transparent}

Fine grain, white flesh, tender, juicy. Medium size. Good quality for eating and the very best for cooking. The tree is a vigorous grower and succeeds best on thin soil. Ripens among the earliest.

\section{Red June}

Medium to large, a beautiful bright red, flesh white, very tender and highly flavored. Splendid eating apple.

\section{Duchess of Oldenberg}

The Duchess is a very attractive, smooth skinned yellow apple, streaked and shaded red. A favorite because of rich acidity and splendid cooking qualities. Large and regularly shaped. Trees can be planted close. Comes into bearing young, producing abundant crops.

\section{AUTUMN APPLES}

\section{Maiden's Blush}

Rather large, pale yellow with beautiful blush. Valuable for market and one of the best for drying as it makes a white product. Tree a fine grower and pro-. ductive.

\section{Grimes' Golden}

Medium size, oblong. Delicate aromatic flavor. Excellent for eating raw and cooking. Tree hardy and vigorous.

\section{Wealthy}

The Wealthy is a hardy, showy bright red apple, rather large and uniform in shape. The skin is tough so that it stands handling well. A free grower, very productive, good quality.

\section{Rome Beauty}

Large, uniform, smooth apple. Yellow, streaked with red, good cooker. A gond market apple. Keeps well.

\section{Virginia Beauty}

Dark dull red apple. Juicy, rich and splendid flavor. Good keeper. 


\section{CHERRIES}

There are few more desirable fruits than the cherry. They are being planted more and more each year and there is always a demand on the market for good fruit. The fruit is delicious whether eaten out of hand or preserved.

\section{Governor Wood}

Large, rich light yellow with red cheek. Juicy and sweet.

\section{May Duke}

One of the best cherries. Roundish and growing in clusters and when fully ripe of a rich dark red of a rich, excellent flavor.

\section{Dyehouse}

Very early and a sure bearer. Quality very good.

\section{Early Richmond}

Ripens in May. Fruit bright red. Very sure. Tree thrifty, healthy and heavy bearer. A good commercial variety as it has an established market.

\section{Montmorency}

One of the largest of sour cherries, fruit being bright red. Solid flesh. Tree hardy and very prolific. One of the best for canning and preserving.

\section{Black Tartarian}

The largest of sweet cherries. Purplish black. Mild, juicy, and tender flesh. The tree is strong growing and produces immense crops. One of the most profitable varieties to grow.

\section{Yellow Spanish}

An inch in diameter. Pąle yellow. Delicious. Yields abundant crops.

\section{English Morello}

Medium to large, roundish, dark red, nearly black. Very good.

\section{APRICOTS}

A beautiful and delicious fruit, a close relative to plum and peach. The fruit ripens after the early cherries and just before the plum and peaches. Tree is hardy and requires about the same cultivation as peach.

\section{Moorpark}

Orange yellow, sweet, juicy and rich.

\section{Superb}

The best apricot now being offered. Magnificent tree, large and spreading. A beautiful yellow with slight blush. Firm and solid. 


\section{PLUMS}

Plums come into bearing early and rarely ever fail to produce a good crop of fruit, and their excellent flavor can never fail to be appreciated. Nothing finer for preserves and jellies.

\section{Red June}

Early. Ripens with early peaches. Color, red all ovtr. Flesh yellow and very fine quality.

\section{Abundance}

A popular Japan variety, hardy and thrifty, fruit large, showy, rich and juicy.

\section{Climax}

Very large. Extremely early. Skin thick and separates easily from flesh. Tree is a vigorous grower and very productive.

\section{Burbank}

Large, clear cherry, red; flesh, deep yellow, very sweet. Very prolific. The tree is vigorous in growth and succeeds well in all sections.

\section{Wild Goose}

Large, somewhat obling. Bright red. Juicy, sweet. Good quality. A very showy and fine market fruit. Profitable for early shipments.

\section{Wickson}

A remarkably handsome and very large plum. Flesh firm, deep amber color. Ot first quality and an excellent keeper.

\section{Satsuma}

Large, dark purplish red. Well flavored. Ripens in August.

\section{Shropshire Damson}

One of the best. Dark purple with blue bloom. Flesh melting, juicy. Quality good. A valuable fruit for cooking, canning and preserving. 


\section{PEARS}

The cultivation of this fruit is extending as its value is appreciated and the demand increasing every year. Pears are so delicious that they should have a promlnent place in the home orchard, as well as an important consideration as a market crop.

\section{Koonce}

\section{SUMMER PEARS}

Medium to large size, yellow, one side covered with red. Dues not rot at core. Very productive, handsome and vigorous.

\section{Early Harvest}

Tree a strong grower, hardy. Fruit large, yellow. Ripens first of July.

\section{Bartlett}

Large size. Buttery, very juicy and highly flavored. Tree a strong grower. Bears early and abundantly. Very popular.

\section{Clapp's Favorite}

A large, fine pear, fine texture, juicy, with a delicious flavor. Tree hardy and productive.

\section{Flemish Beauty}

\section{AUTUMN PEARS}

Large, sweet and rich, excellent flavor. Strong grower and good bearer.

\section{Garber}

Fine quality.

Bright yellow with red. A splendid canning pear. Tree vigorous and hardy.

\section{Kieffer}

Most popular pear grown; fruit of fine size, rich color and good quality. Tree very vigorous and seldom blights.

\section{QUINCE}

\section{Orange}

Large, roundish, bright golden yellow. Cooks tender and is of excellent flavor. Best known and good variety.

\section{Champion}

Strong, free grower and comes into bearing very young. Very large and handsome. Cooks tender as an apple. A valuable sort. 


\section{GRAPES}

Grapes may be classed among the most beautiful, useful and wholesome of fruits. Any one who has a garden, yard or wall can grow grapes and if proper selection of varieties is made one may have grapes for several months. To grow for market they can be planted on hillsides that are unsuitable for other crops, but must be given attention. We give the following varieties in order of ripening.

Campbell's Early

Black. Clusters, grapes large and perfect, flavor rich and sweet. A fine keeper. Vine vigorous and productive.

\section{Brighton, Red}

Bunch medium, flesh rich and sweet.

\section{Moore's Early, Black}

Bunch extra large. Extreme hardiness and size render it a popular market sort.

\section{Lutie}

One of the best for home and local market. Brownish red. Bunches and berries large. Quality, sweet and sugary.

\section{Concord, Black}

The best all round grape grown. Vine hardy, vigorous and pröductive.

\section{Delaware, Red}

Small. Quality much admired. Vine is slender but grows freely and is hardy.

\section{Niagara, White}

A magnificent grape and very valuable. Rapid grower and very'-productive of beautiful bunches of largest size.

Catawba, Red

Large bunch, large berries. Flavor rich and sweet. 


\section{STRAWBERRIES}

The strawberry being the first fruit to ripen in the spring is very welcome. No fruit can surpass strawberries, fully ripe and freshly picked. They come to the table in tempting style. The charms of the strawberry do not end in the eating. They are sure to grow. The culture is simple and fine berries are sure to sell at paying prices.

\section{Klond.yke Early}

Berries uniform, dark red, mild and delicious. Plants make a remarkable growth, and abundant runners. Yields are wonderful. Best paying early berry and is good shipper, always demanding good prices.

\section{St. Louis}

Large, long, light red, seeds prominent. Plant very strong. An excellent variety.

\section{Excelsior}

One of the best, plant vigorous, berries medium, round and delicious.

\section{Bubach}

A handsome berry, large size. Berries thick and fine grained. One of the most profitable of its season.

\section{Shuckless}

The most remarkable strawberry ever introduced. In picking it parts readily from the stem, the shucks remaining on the stem instead of the berry. Plant a strong grower. Produces berries of uniform size and color.

\section{Haverland}

This is one of the best mid-season varieties. Makes runners enough without planting thickly.

\section{Tennessee Prolific}

A very fine berry, a vigorous and thrifty grower. The berries are large and even in size. Should be planted by all berry growers either for market or for home use.

\section{Gandy}

Holds first place as a late berry. Large, regular, bright crimson, firm and fine flavor. 


\section{RASPBERRIES}

Coming immediately after strawberries when there is no other fruit, raspberries are equally desirable for planting in the garden for home use, and in the field for market. I asts over a periud of three weeks or more.

\section{Cuthert}

Most reliable variety for the south. Of large size and fine flavor. An enormous bearer. Excellent for market and shipping. Largely used everywhere and best of its color.

\section{Cumberland}

Black. Very large. Firm and excellent quality. Hardy and productive. One of the best market berries.

\section{Gregg}

Of good size, fine quality, very productive and hardy. No one can afford to be without this varięty.

\section{St. Regis}

Everbearing. Bright crimson, firn, rich, delicious flavor, ships well. Of iron clad hardiness.

\section{BLACKBERRIES}

Blackberries are among the best known and valued of the small fruits, very wholesome and good. They are easy of cultivation and will grow in any garden soil.

\section{Early Harvest}

A standard, early sort. Ripens early. Tender, very juicy and sweet.

\section{Mersereau}

An enormous producer of extra large berries. Brilliant black. Extra quality. Sweet, rich and juicy.

\section{Snyder}

Extremely hardy and very prolific. Berries medium size, rich and good. Fruits in clusters. Easy to pick.

\section{Eldorado}

Vines vigorous and productive. Berries jet black. Borne in large clusters. Su eet and pleasant. Good keeper and shipper. 
Scale 20 feet to the inch.

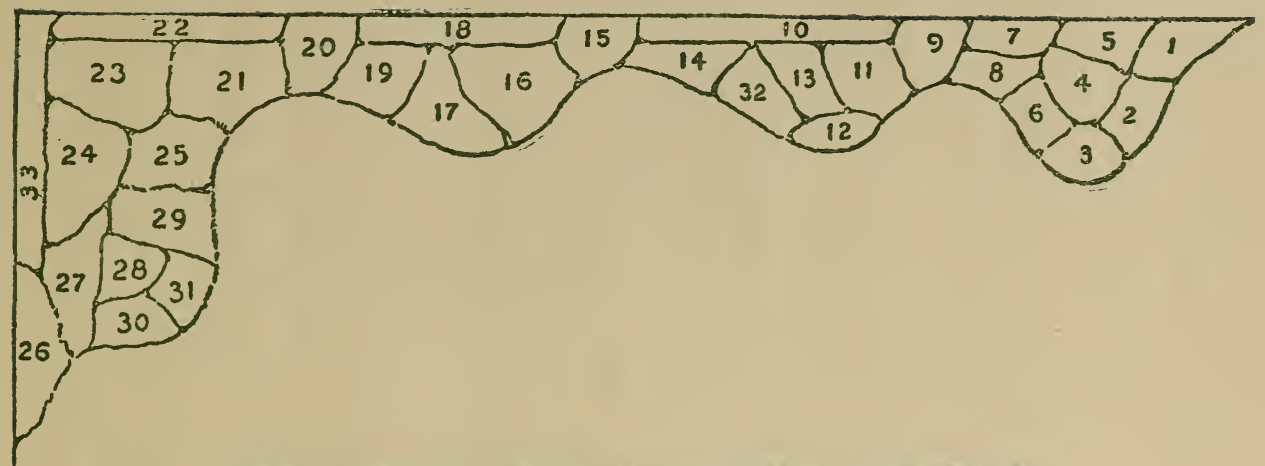

SUGGESTION FOR PLANTING BORDER

1. One Hercules Club.

2. Five Weigelia Eva Rathke.

3. Five Deutzia Gracilis.

4. Ten Althea Hibiscus, Syriacus.

5. Three Lilac Purple, Syringa Vulgaris.

6. Five Spirea Van Houtii.

7. Six Dogwood Red Twig. Cornus Siberica.

8. Twenty Blanket Flower, Gaillardia.

9. Two Upland Cranberry, Viburnum Opulus.

10. Five Irish Juniper.

11. Five Hydrangea Arborescens.

12. Eight Japanese Berberry.

13. Three Golden Elder, Sambucus Nigra var. Aurea.

14. Ten Hardy Hibiscus, Hibiscus Moschentos.

15. Twelve Fox Glove. Digitalis.

16. Seven Hydrangea P. G.

17. Six Spirea A. Waterer.
18. Five Siberian Arborvitae.

19. Fifteen Phlox, red and white.

20. Two Forsythia Intermedia.

21. Thirty Garden Pinks, Dianthus Chinensis.

22. Eight Spruce, European White.

23. Five Sumac Cut Leaf, Rhus Coronaria.

24. Three Syringa, Philadelphus Grandiflora.

25. Two Witch Hazel, Hammamelis Virginica.

26. Fifteen Hardy Sunflower, Helianthus.

27. Seven Spirea Billardia.

28. Ten Coreopsis Lanceolata.

29. Two Lilac Persian, Syringa Persica.

30. Five Mahonia Aquifolia, Berberis Aquifolium.

31. Two Shasta Daisy.

32. Thirty Forget-Me-Not, Myosotis Palustris.

33. Five Arborvitae, Pyramidalis.

\section{INDEX}

Page

Apple

Apple Culture

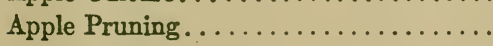

Apple Dwarf....................

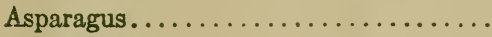

Blackberries...................

Buying, Economy in ..............

Bulbs.................... 22-23-34

Bulbs, Summer Blooming. . . . . . . . . . 24

Cherry....................... 7

Currants..................... 10

Digging Hole. . . . . . . . . . . . . 4

Evergreens.................... 14-30

Evergreens, Broad Leaved. . . . . . . . . . 14-30

Fruits for Special Purposes.......... 29

Grapes......................... 9

Gooseberries.................. 10

Eledges................... 26-27-28
Page

Plant Immediately. . . . . . . . . . . . . 5

Plans for Orchards................. 6

Pear.......................... 7

Peach....................... 8

Plum........................ 8

Perennials................ 19-10-20-34

Peony........................ 25

Preparing Land................. 4

Pruning....................... 5

Quince....................... 9

Raspberry.................... 11

Roses.................... 20-21-22

Rhubarb..................... 11

Strawberries................... 9-10

Shade Trees.................. 14-30

Shrubs................... 15-31-32-33

Vines..................... 16-17-18

Windbreaks................. 28 




